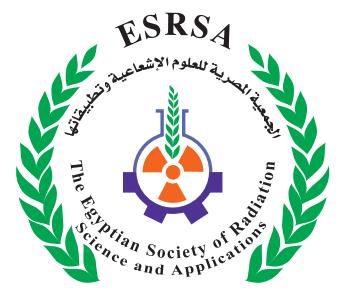

J. Nucl. Tech. Appl. Sci., Vol. 7, PP. 79 : 100 (2019)

\title{
Evaluation of Environmental Impact of Iron and Steel Industry in Egypt; Radiological and Heavy Metals Contribution
}

Mohamed, R.S. ${ }^{1}$; Bakr, W.F. ${ }^{\text {; }}$ Arafat, A.A. ${ }^{1}$; El Hemamy, S.T. ${ }^{\text {; }}$ and Abo-Aly, M.M. ${ }^{2}$

Received: 09/09/2018

Accepted: 01/10/2018

E.mail:raniabadway@yahoo.com

\section{KEYWORDS}

Natural

Radionuclides,

Radiological Hazards,

Heavy Metals,

Pollution Indices.

\section{ABSTRACT}

This study is established to evaluate the impact of iron and steel industry in Egypt on the public and environment.The study involved five companies for iron and steel production. Forty-two raw materials samples, eight waste sampleswere collected from the selected companies as well as sixty-eight soil samples were collected inside and around the companies.

The activity concentrations of ${ }^{226} \mathrm{Ra},{ }^{232} \mathrm{Th},{ }^{40} \mathrm{~K}$ and ${ }^{137} \mathrm{Cs}$ were determined applying Hyper-Pure Germanium (HPGe) detector. Radiological health parameters such as radium equivalent,annual gonadal equivalent dose and excess lifetime cancer risk were estimated to assess health implication of exposure to the general public and workers to the studied samples. Heavy metals ( $\mathrm{Cd}, \mathrm{Cr}, \mathrm{Cu}, \mathrm{Fe}, \mathrm{Mn}, \mathrm{Ni}, \mathrm{Pb}, \mathrm{Zn}$, and $\mathrm{As}$ ) were determined by ICP- OES. Contamination factor, contamination degree and pollution load index of heavy metals were estimated; in addition pollution load index (PLI) of zones was used to compare the pollution levels between the studied companies.

The activity concentration of ${ }^{226} \mathrm{Ra},{ }^{232} \mathrm{Th},{ }^{40} \mathrm{~K}$, and ${ }^{137} \mathrm{Cs}$ in soil samples ranged from $<0.7$ to $257.5,<0.6$ to $25.4,3.63$ to 1578 , and $<0.04$ to $18.6 \mathrm{Bqkg}^{-1}$ respectively. Soil samples have hazard indices within safe limit and don't pose a significant health hazard except some soil samples around the first company. Concentration of $\mathrm{Cd}, \mathrm{Cr}, \mathrm{Cu}, \mathrm{Fe}, \mathrm{Mn}, \mathrm{Ni}, \mathrm{Pb}$, $\mathrm{Zn}$, and As ranged from (0.038 to 57), (2.265 to 922.65), (3.97 to 774.2),

1. Egyptian Nuclear and Radiological Regulatory Authority, 3 Ahmed El Zomor St., P.O.B.7551, Nasr City, 11762 Cairo, Egypt.

2. Ain Shams University, Faculty of Science, Chemistry Department, Cairo, Egypt. 
(5184.3 to 99669.2$),(94.2$ to 17299$),(4.00$ to 129.5), (6.0 to 1322.7), (43.2 to 2716.1), and (0.025 to 22.3) ppm respectively. The most polluted zone is the third company showing PLI $=3.3$ and the most contributed site is S50 beside the electric arc furnace as a result of its elevated concentrations of $\mathrm{Cd}, \mathrm{Zn}$, and $\mathrm{Pb}$.

The obtained results are used as a baseline data for monitoring possible radioactivity and heavy metals pollutions in the future around the iron and steel industry in Egypt.Some recommendation should be carried out such as Erasing contaminated soil and monitoring the accumulation of heavy metals in soil samples is very important.

\section{INTRODUCTION}

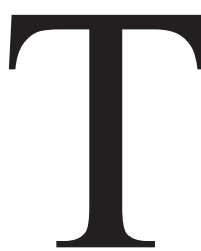

he earth's natural radioactivity can be broadly classified into two categories: high energy cosmic rays incident on the Earth's atmosphere, commonly termed cosmic radiation, and radioactive nuclides generated during the formation of the Earth and still present in the Earth's crust, commonly termed terrestrial radiation. Terrestrial radioactivity is mostly produced by ${ }^{238} \mathrm{U},{ }^{232} \mathrm{Th}$ series radionuclides, as well as ${ }^{40} \mathrm{~K}$ (EC, 2015).

The naturally occurring radioactive materials (NORMs) are found in various geological formations such as soil, rocks, water, air as well as building materials (Avwiri et al., 2014) also in houses with varying degree of concentrations depending on the geographical conditions and geologic formations (Zivanovic et al., 2012 ; Huang et al., 2015). Soil radionuclide activity concentration is one of the main determinants of the natural background radiation. When rocks are disintegrated through natural process, radionuclides are carried to soil by rain and flows (Taskin et al., 2009). In addition to the natural sources, soil radioactivity is also affected by humanmade activities. The radioactivity concentrations in soil give information on both natural and man-made sources which is important in radiological monitoring and assessment of radiation dose for public (EPA, 2007). Studies of natural radioactivity are necessary not only for their radiological impact but also for their ability to act as excellent biochemical and geochemical traces in the environment (Surinder Singh et al., 2003). Natural sources contribute almost $80 \%$ of the collective radiation exposure of the world's population (Kaleel and Mohanad 2012).

Soils vary across the landscape; therefore, each soil sample contains unique trace element concentrations based on its parent material and other soilforming factors that may have added or removed these elements from the soil. High background concentrations of trace elements, whether natural or anthropogenic,could result in mobilization and release into surface and subsurface waters also subsequent incorporation into the food chain. The high levels of heavy metals and other pollutants in the soil samples have been attributed to metal rich source rocks, atmospheric pollution from motor vehicles, combustion of fossil fuels, agricultural fertilizers and pesticides, organic manures, disposal of urban and industrial wastes, as well as mining and smelting processes (Alloway 1990; Brumelis et al., 1999).

The steel industry uses the same raw materials in different production process as a source of steel, where the production of steel carried out by two methods: (1) The blast furnace method in which iron oxide ore is the major raw material for steel production (The First Environmental Conference, 2004), (2) The electric arc method in which the main source of steel is scrap (Integrated Management System Manual, 2005).

Steel is an alloy that contains more than $50 \%$ of iron and $0.03-1.5 \%$ of carbon and to obtain the properties described for different purposes, other metals are usually added (Umland and Bellama, 1996). Some of these metals include; $\mathrm{Mn}, \mathrm{Zn}, \mathrm{Ni}, \mathrm{Cr}$ and V.Mn is the only metal without any substitute that is used as a deoxidizing and desulfuring agent in 
the manufacture of steel. $\mathrm{Zn}$ is used in galvanizing steel to give a protective coating against corrosion. $\mathrm{Ni}$ and $\mathrm{Cr}$ are used for producing stainless steel and high temperature alloys of steel (Leet $\boldsymbol{e t}$ al., 1982). $\mathrm{V}$ used in the manufacture of steel makes the metal more ductile and resistant to shock.On the other hand during the manufacture of steel by electric arc furnace (EAF) method, the result dust is hazardous and toxic, since it contains soluble oxides such as $\mathrm{Cd}$, $\mathrm{Pb}, \mathrm{As}$, and $\mathrm{Cr}$ which are formed at high temperature above the steel bath and in the off-gas systems of the EAF (Lopez el al., 1996). After disposal of flue dust in landfills, these soluble oxides find their way into the water Table, causing pollution. The EAFDis produced in large quantities $(15 \mathrm{~kg} / \mathrm{t})$ during manufacture of steel (Lopez el al., 1996). We must mention that many studies detected ${ }^{137} \mathrm{Cs}$ in the EAFD (Keck et al., 1994; Kugeler and Thierfeldt, 1999; Tahir et al., 2010) and United States Environmental Protection Agency (EPA) categorized it as hazard waste (Nadeem et al., 2016). Iron and steel industry is significant source for atmospheric emission pollutants (IPPC, 2001).

Soil is a great geochemical reservoir for contaminant as well as a natural buffer for transportation of chemical materials and elements in the atmosphere, hydrosphere, and biomass. So, it is the most important component of the human biosphere. As soil is an important constituent of the human biosphere, any harmful change to this segment of the environment seriously affects the overall quality of human life. The most adverse effect of heavy metals is that they can be introduced into the food chain and threaten human health.

According to Udosen et al. (1990), heavy metals in soil are associated with geometrical cycles and biological processes and could be greatly influenced by industrial activities.In particular, heavy metal pollution of soils due to intense industrialization and urbanization has become a serious concern in many developing countries (Wei and Yang, 2010; Yaylali-
Abanuz, 2011), and worldwide (Alloway, 1995).

The main objective of this work is to measure the activity concentration levels of ${ }^{226} \mathrm{Ra},{ }^{232} \mathrm{Th},{ }^{40} \mathrm{~K}$ and

${ }^{137}$ Csin raw materials(such as Dolomite, flour spare, lime and coke), waste (slag and EAFD) and soil samples. These measurements are aimed to estimate hazard indices (Absorbed dose rate, annual effective dose, external radiation hazard index, radioactivity level index, annual gonadal equivalent dose and excess lifetime cancer risk). Also the concentration of heavy metals was measured; in addition to calculate pollution indices (contamination factor, contamination degree and pollution load index and pollution load index of zone). This type of measurements is of great importance in drawing a clear picture about the radiological and chemical implications of iron and steel industry on its workers, public and the surrounding environment.

\section{MATERIALS AND METHODS}

\section{Sampling Locations}

The present study involved five factories of iron and steel production in Egypt located in Cairo, Alexandria, El Sadat city and El Suez as indicated in Figure 1.

A total of 118samples namely; forty-two raw materials and eight waste samples included slag, scale,dust from EAF, brick fromEAFand dust besidedirect reduced plant (DRP)were collected from companiesin addition to sixty-eight soil samples were collected from inside and around the five factories.Twenty soil samples were collected around the first company which located in Cairo.Thirteen raw materials, two waste samples (slag and dust beside DRP) and twenty soil samples were collected inside and aroundthe second company which located in Alexandria. Twelve raw materials, two waste (slag and brick from EAF) and nine soil samples were collected inside and around the third company which located in El Sadat city. Eight raw materials, three 
waste (slag, scale and dust from EAF) and nine soil samples were collected inside and around the fourth company which located in El Sadat city. Nine raw materials, one waste (scale) and eight soil samples were collected inside and around the fifth company- which located in El Suez city. The coordinates of all sampling points were identified by the Global Positioning System device (GPS, eTrex, Personal Navigator, Garmin Ltd).

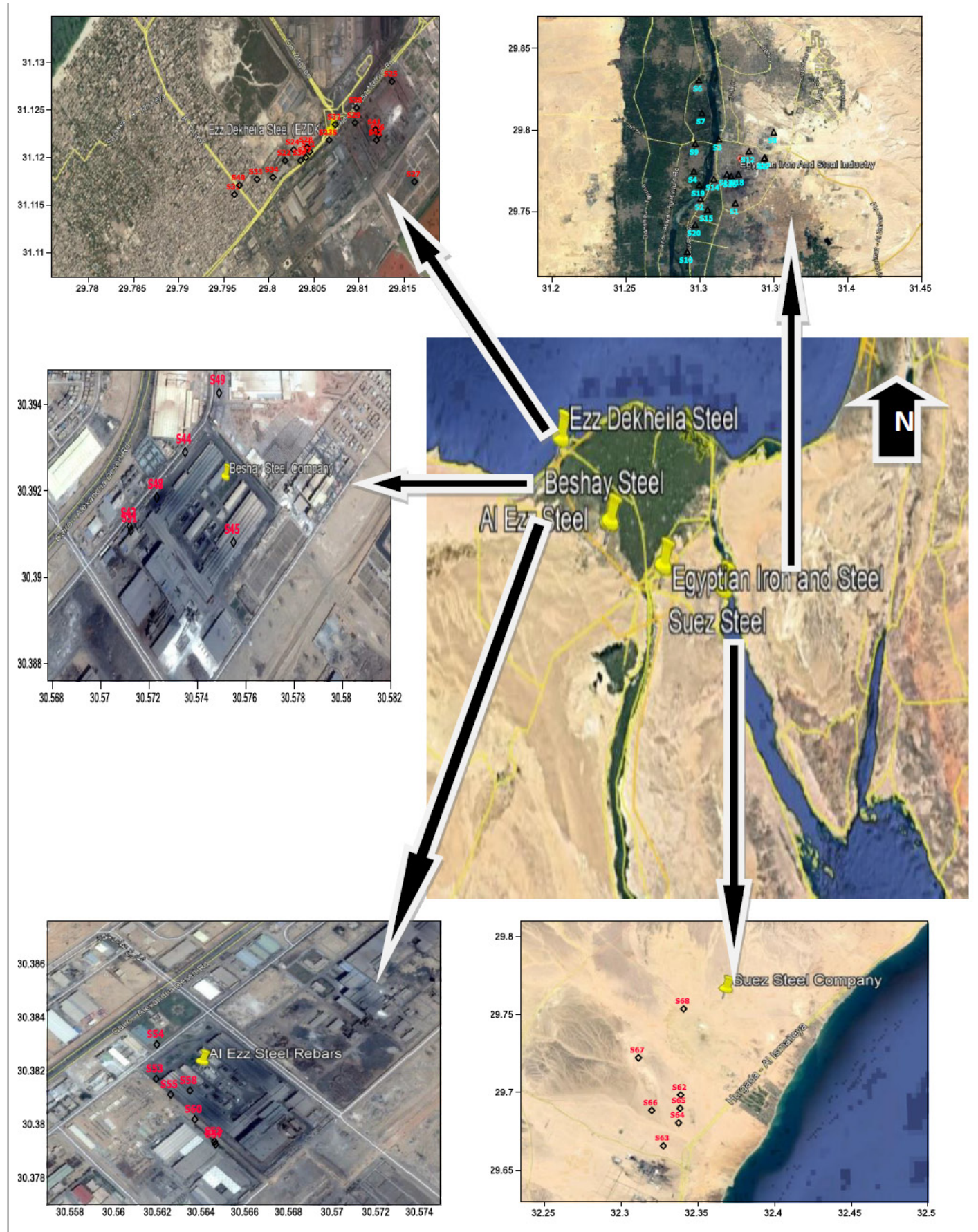

Fig. (1): Location map of the studied area indicating sampling points. 


\section{Samples preparation for gamma measurement}

Samples were oven dried at a temperature of $110^{\circ} \mathrm{C}$ for about 24 hours to insure removal of moisture (Alam et al., 1997). Then mixed homogeneously and passed through a $1 \mathrm{~mm}$ sieve (Tufail et al., 2006). $100 \mathrm{ml}$ of samples was weighed by an electrical balance and transferred into polyethylene container that marked individually with identification parameters e.g., name and location of the sample, date of preparation and net weight. The polyethylene container was sealed tightly with insulating tape to prevent the escape of radon daughters. The samples were stored and kept for a period of 1 month to attain secular radioactive equilibrium between ${ }^{232} \mathrm{Th}$ series and ${ }^{226} \mathrm{Ra}$ - contents of the sample and their daughters (Kurnaz et al., 2007; Samad et al., 2012).

\section{Soil preparation for ICP-OES}

All soil samples were digested according to method 3050B (EPA, 1996). The digested samples were diluted to $100 \mathrm{ml}$ with deionized water, filtrated into polyethylene bottles and introduced for heavy metal analysis using ICP-OES.

\section{Radioactive Measurements}

The detection and measurement of radionuclides in the samples were carried out by gamma spectrometry system based on high purity germanium (HPGe) detector with $40 \%$ relative efficiency. The p-type HPGe detector supplied by CANBERRA had a resolution of $1.9 \mathrm{keV}$ at $1332 \mathrm{keV}$ of Cobalt-60 gamma-ray line. The device was calibrated for efficiency using standard method described in ElTahawy et al. (1992). Depending on sample activity, spectra were recorded for time $82000 \mathrm{~s}$, and analyzed using the GENIE 2000 CANBERRA software. The background was used to determine the limit of detection and minimum detectable activity (MDA) according to Currie (1968). The minimum detectable activities at $95 \%$ confidence level for the detecting system were $0.7,0.6,3.0$, and $0.04 \mathrm{Bqkg}^{-1}$ for ${ }^{226} \mathrm{Ra},{ }^{232} \mathrm{Th},{ }^{40} \mathrm{~K}$, and ${ }^{137} \mathrm{Cs}$, respectively. The ${ }^{232} \mathrm{Th}$ was determined from the average concentrations of ${ }^{228} \mathrm{Ac}(338.32 \mathrm{keV}, 911 \mathrm{keV}, 968.97 \mathrm{keV})$ and ${ }^{208} \mathrm{Tl}$ $(583.19 \mathrm{keV})$ in the samples and the ${ }^{226} \mathrm{Ra}$ was determined from the average concentration of the ${ }^{214} \mathrm{~Pb}$ (351.9 keV) and ${ }^{214} \mathrm{Bi}(609.3,1120$, and $1764.5 \mathrm{keV})$ decay products. The ${ }^{40} \mathrm{~K}$ and ${ }^{137} \mathrm{Cs}$ were determined directly from $1460.8 \mathrm{keV}$ and $661.6 \mathrm{keV}$, respectively (Roessier et al., 1970; IAEA, 1989).

The activity concentration of a certain radionuclide, $\mathrm{A}\left(\mathrm{Bqkg}^{-1}\right)$, in the samples was calculated using the following equation (Knoll, 1998; Abdel-Ghany, 2010).

$A\left(\right.$ Bq kg $\left.^{-1}\right)=\frac{C_{a}}{\left(\varepsilon \cdot I_{\text {eff }} \cdot M_{S}\right)}$

Where $\boldsymbol{C}_{\boldsymbol{a}}$ is the net gamma counting rate (counts per second) for a peak at energy $E, \varepsilon$ is the detected efficiency of a specific $\gamma$-ray, $I_{\text {eff }}$ is the intensity of the $\gamma$-line in radionuclides, and $M_{s}$ is the mass of the sample in kilograms.

\section{RADIOLOGICAL HAZARD INDICES CALCU- LATIONS}

\section{Radium Equivalent $\left(R a_{e q}\right)$}

$\mathrm{Ra}_{\mathrm{eq}}$ is weighted sum of specific activities ${ }^{226} \mathrm{Ra}$, ${ }^{232} \mathrm{Th}$ and ${ }^{40} \mathrm{~K}$ based on the estimation that $370 \mathrm{Bqkg}^{-1}$ of ${ }^{226} \mathrm{Ra}, 259 \mathrm{Bqkg}^{-1}$ of ${ }^{232} \mathrm{Th}$ and $4810 \mathrm{Bqkg}^{-1}$ of ${ }^{40} \mathrm{~K}$ generate the same gamma dose rate (Beretka and Mathew, 1985; Ndontchueng et al., 2014). The calculation of $\mathrm{Ra}_{\mathrm{eq}}$ is based on the following relation:

$R a_{e q}\left(\mathrm{Bqkg}^{-1}\right)=A_{R a}+1.43 A_{T h}+0.077 A_{k}(2)$

Where $\mathrm{A}_{\mathrm{Ra}}, \mathrm{A}_{\mathrm{Th}}$ and $\mathrm{A}_{\mathrm{k}}$ are activity concentrations of ${ }^{226} \mathrm{Ra},{ }^{232} \mathrm{Th}$ and ${ }^{40} \mathrm{Kin}_{\mathrm{Bqkg}}{ }^{-1}$ respectively.

\section{Absorbed Gamma Dose Rate $D_{r}(n G y / h)$}

The absorbed gamma dose rate was assessed utilizing the activities concentrations of the ${ }^{226} \mathrm{Ra}$, ${ }^{232} \mathrm{Th}$ and ${ }^{40} \mathrm{~K}$ measured for samples and using dose coefficients $0.462,0.604$ and 0.0417 for ${ }^{226} \mathrm{Ra},{ }^{232} \mathrm{Th}$ and ${ }^{40} \mathrm{~K}$ respectively, the following equation has been 
used for calculate absorbed gamma dose rate (UNSCEAR, 2000):

$D_{r}(n G y / h)=0.462 A_{R a}+0.604 A_{T h}+0.0417 A_{k}$

Where $\mathrm{A}_{\mathrm{Ra}}, \mathrm{A}_{\mathrm{Th}}$ and $\mathrm{A}_{\mathrm{k}}$ are activity concentrations of ${ }^{226} \mathrm{Ra},{ }^{232} \mathrm{Th}$ and ${ }^{40} \mathrm{~K}$ respectively in $\mathrm{Bqkg}^{-1}$.

\section{Annual Effective Dose Equivalent (AEDE)}

Applying the conversion factor of 0.7 (Sv/Gy), which converts absorbed dose $D_{r}$ in air to human effective dose and using an outdoor occupancy factor of 0.2 as recommended by UNSCEAR (2000). The annual effective dose equivalent was calculated from following relation:

$A E D E(\mu S v / y)=D_{r}\left(\mathrm{nGyh}^{-1}\right) \times 8760 h \times 0.7(S v / G y)$ $\times 0.2 \times 10^{-3}$ (4)

\section{Gamma Radiation Representative Level Index (I $\gamma$ )}

Gamma radiation representative level index is another radiation hazard index used for the evaluation of the external exposure to $\gamma$-ray associated with the natural radionuclides $\left({ }^{226} \mathrm{Ra},{ }^{232} \mathrm{Th}\right.$ and $\left.{ }^{40} \mathrm{~K}\right)$, it is calculated according to the following equation (NEA-OECD, 1979; UNSCEAR, 2000; Shanthi $e t$ al., 2010):

$I_{\gamma}=\left(A_{R a} / 150\right)+\left(A_{T h} / 100\right)+\left(A_{K} / 1500\right) \leq 1(5)$

Where $\mathrm{A}_{\mathrm{Ra}}, \mathrm{A}_{\mathrm{Th}}$ and $\mathrm{A}_{\mathrm{k}}$ are activity concentrations of ${ }^{226} \mathrm{Ra},{ }^{232} \mathrm{Th}$ and ${ }^{40} \mathrm{~K}$ in $\mathrm{Bqkg}{ }^{-1}$ respectively.

\section{Annual Gonadal Equivalent Dose (AGED)}

The annual gonadal equivalent dose is a measure of the genetic significance of the yearly dose received by the population's reproductive organs (Ravisankar et al., 2014). Organs with rapidly dividing cells such as gonads, and the active bone marrow and bone surface cells are considered as organs of interest by UNSCEAR, (2000). The increase in AGED has been known to affect the bone marrow, causing destruction of the red blood cells that are then replaced by white blood cells. This situation results in a blood cancer called leukemia which is fatal.
AGED due to specific activities of ${ }^{226} \mathrm{Ra},{ }^{232} \mathrm{Th}$ and ${ }^{40} \mathrm{~K}$ was estimated using the following formula (Mamont - Ciesla et al., 1982; Vohra et al., 1982; Avwiri et al., 2014).

$A G E D\left(m S v y^{-1}\right)=3.09 A_{\mathrm{Ra}}+4.18 A_{\mathrm{Th}}+0.314 A_{\mathrm{K}} \quad$ (6)

Where $\mathrm{A}_{\mathrm{Ra}}, \mathrm{A}_{\mathrm{Th}}$ and $\mathrm{A}_{\mathrm{k}}$ are activity concentrations of ${ }^{226} \mathrm{Ra},{ }^{232} \mathrm{Th}$ and ${ }^{40} \mathrm{~K}$ in $\mathrm{Bqkg}{ }^{-1}$ respectively.

\section{Excess Lifetime Cancer Risk (ELCR)}

The excess lifetime cancer risk (ELCR) gives the probability of developing cancer over a lifetime at a given exposure level, considering 70 years as the average duration of life for human being (Taskin et al., 2009). Radioactivity in building materials are known to produce carcinogenic effects due to accumulation of radon and its progenies in air that emanate from the wall and floor of a room. The excess lifetime cancer risk (ELCR) gives the probability of developing cancer over a lifetime at a given exposure level, considering 70 years as the average duration of life for human being (Taskin et al., 2009).

Based upon calculated values of annual effective dose (AEDE), ELCR was estimated using the following formula (Taskin et al., 2009; Ramasamy, 2011; Qureshi et al., 2014):

$E L C E R=A E D E \times D L \times R F$

AEDE is the annual effective dose equivalent, DL isduration of life (estimated to be 70 years) and $\mathrm{RF}$ isrisk factor $\left(\mathrm{Sv}^{-1}\right)$ which reflects the fatal cancer risk per Sievert. For stochastic effects, ICRP-106 (ICRP, 2008) uses RF as $0.05 \mathrm{~Sv}^{-1}$ for the general public.

ASSESMENT OF HEAYVY METAL POLLUTION

\section{Contamination Factor and Degree of Contamina-} tion

The assessment of soil contamination was carried out using the contamination factor. Contamina- 
tion factors $\left(C_{f}^{i}\right)$ were calculated to evaluate the level of contamination of each element, according to the following equation (Tippie, 1984).

$C_{f}^{i}=\frac{C_{0-1}^{i}}{C_{n}^{i}}$

Where $C_{0-1}^{i}$ is the measured concentration of the examined metal $\mathrm{i}$ in the soil sample, and $C_{n}^{i}$ is the background concentration of individual metal.In the present study a modification has applied thefactor as indicated by Krzysztof $\boldsymbol{e t}$ al., (2003) where the concentration of elements in the earth's crust is used as a reference value, used as $C_{n}^{i}$.

Four contamination categories are documented on the basis of the contamination factor (Hakanson, 1980). $C_{f}^{i}<1$ low contamination; $1 \leq C_{f}^{i} \geq 3$ moderate contamination; $3 \leq C_{f}^{i}<6$ considerable contamination; $C_{f}^{i}>6$ very high contamination.

The sum of contamination factors for all elements examined represents the degree of contamination $\left(\mathrm{C}_{\mathrm{deg}}\right)$ of the site and all four classes were recognized (Hakanson, 1980).

$$
C_{d e g}=\Sigma C_{f}^{i}
$$

Where, $C_{d e g}$ is the degree of contamination in a particular sampling site and $C_{f}^{i}$ is contamination factor. The following terms is adopted to illustrate the degree of Contamination: $C_{\text {deg }}<8$ : low degree of Contamination; $8 \leq C_{d e g}<16$ : moderate degree of contamination; $16 \leq C_{d e g}<32$ : considerable degree of contamination; $C_{d e g}>32$ : very high degree of contamination indicating serious anthropogenic pollution (Hakanson, 1980).

\section{Pollution Load Index}

The pollution load index (PLI) was proposed by Tomlinson et al. (1980) for detecting pollution which permits a comparison of pollution levels between sites. The PLI was obtained as a concentration factor of each heavy metal with respect to the background value in the soil.
A PLI $<1$ indicates perfection pollution; a $\mathrm{PLI}=1$ indicates Base line level of pollution and PLI $>1$ indicates deterioration of site quality (Usero and Garcia. 2000). The PLI has been calculated according to the following equation (Tomlinson et al., 1980):

$$
\boldsymbol{P L I}=\left(C_{f_{1}}^{i} \times C_{f_{2}}^{i} \times C_{f_{3}}^{i} \times C_{f_{n}}^{i}\right)^{1 / n}
$$

Where, $n$ is the number of metals studied and $C_{f}^{i}$ $C_{f}^{i}$ is the contamination factor as mentioned above.

Site indices can be treated in exactly the same way to give a pollution load index for zone.

$$
\text { PLI for zone }=\sqrt[n]{P L I_{1} . P L I_{2} \ldots \ldots \ldots P L I_{n}}
$$

Where, PLI is pollution load index and $\mathrm{n}$ equals the number of sites.

\section{RESULTS}

\section{Activity Concentrations}

The results for the activity concentrations (dry weight) of ${ }^{226} \mathrm{Ra},{ }^{232} \mathrm{Th},{ }^{40} \mathrm{~K}$ and ${ }^{137} \mathrm{Cs}$ in soil samples of companies were reported in Table1, and reported as $\mathrm{Bqkg}^{-1}$ dry weight. Soil samples of the first company show activity concentrations ranged from 6.8 to $227.5 \mathrm{Bqkg}^{-1}$ (32.9 $\mathrm{Bqkg}^{-1}$, in average) for ${ }^{226} \mathrm{Ra}$, ranged from 6.7 to $19.3 \mathrm{Bqkg}^{-1}\left(9.8 \mathrm{Bqkg}^{-1}\right.$, in average) for ${ }^{232} \mathrm{Th}$ and ranged from 54.5 to $1578.9 \mathrm{Bqkg}^{-1}$ (216.7 $\mathrm{Bqkg}^{-1}$, in average) for ${ }^{40} \mathrm{~K}$. Soil samples of the second company show activity concentrations ranged from 11.6 to $28.2 \mathrm{Bqkg}^{-1}\left(20.2 \mathrm{Bqkg}^{-1}\right.$, in average) for ${ }^{226} \mathrm{Ra}$, ranged from 6.2 to $25.4 \mathrm{Bqkg}^{-1}(13.6$ $\mathrm{Bqkg}^{-1}$, in average) for ${ }^{232} \mathrm{Th}$ and ranged from 16.4 to 245.3Bqkg-1 $\left(154.2 \mathrm{Bqkg}^{-1}\right.$, in average) for ${ }^{40} \mathrm{~K}$. Soil samples of the third company show activity concentrations ranged from 10.8 to $21.4 \mathrm{Bqkg}^{-1}\left(5.6 \mathrm{Bqkg}^{-1}\right.$, in average) for ${ }^{226} \mathrm{Ra}$, ranged from 7.1 to $13.5 \mathrm{Bqkg}^{-1}$ (11.1 $\mathrm{Bqkg}^{-1}$, in average) for ${ }^{232} \mathrm{Th}$, ranged from 59.9 to $221.5 \mathrm{Bqkg}^{-1}$ (177.3 $\mathrm{Bqkg}^{-1}$, in average) for ${ }^{40} \mathrm{~K}$ and ranged from 0.43 to $18.6 \mathrm{Bqkg}^{-1}\left(8.1 \mathrm{Bqkg}^{-1}\right.$, in average) for ${ }^{137} \mathrm{Cs}$. Soil samples of the fourth company show activity concentrations ranged from 5.7 to $15.9 \mathrm{Bqkg}^{-1}$ (12.3 $\mathrm{Bqkg}^{-1}$, in average) for ${ }^{226} \mathrm{Ra}$, 
ranged from 5.7 to $16.4 \mathrm{Bqkg}^{-1}\left(12.1 \mathrm{Bqkg}^{-1}\right.$, in average) for ${ }^{232} \mathrm{Th}$ and ranged from 112.2 to $202.2 \mathrm{Bqkg}^{-1}$ (165.2 $\mathrm{Bqkg}^{-1}$, in average) for ${ }^{40} \mathrm{~K}$. Soil samples of the fifth company show activity concentrations ranged from 1.7 to $25.4 \mathrm{Bqkg}^{-1}$ (13.0 $\mathrm{Bqkg}^{-1}$, in average) for ${ }^{226} \mathrm{Ra}$,ranged from 1.2 to $11.3 \mathrm{Bqkg}^{-1}\left(6.5 \mathrm{Bqkg}^{-1}\right.$, in average) for ${ }^{232} \mathrm{Th}$ and ranged from 3.6 to $135.2 \mathrm{Bqkg}$ ${ }^{1}\left(58.5 \mathrm{Bqkg}^{-1}\right.$, in average) for ${ }^{40} \mathrm{~K}$.

Table 3 and Table 4 shows the activity concentrations for ${ }^{226} \mathrm{Ra},{ }^{232} \mathrm{Th},{ }^{40} \mathrm{~K}$ and ${ }^{137} \mathrm{Cs}$ of raw materials and waste respectively. The activity concentration of ${ }^{226} \mathrm{Ra}$ ranged from $2.9 \mathrm{Bqkg}^{-1}$ (Si-Mn and $\mathrm{Mn}$ ) to 85.9 $\mathrm{Bqkg}^{-1}$ (Fluorspar) in the second company; from $<0.7 \mathrm{Bqkg}^{-1}$ (Fe-Si-Mn and FeMn) to $82.6 \mathrm{Bqkg}^{-1}$ (Fluorspar) inthe third company; ranged from $<0.7$ $\mathrm{Bqkg}^{-1}$ (Si-Mn and olivine sand filter) to $84.0 \mathrm{Bqkg}$ ${ }^{1}$ (Fluorspar) in the fourth company and from $<0.7$ $\mathrm{Bqkg}^{-1}$ (Fe-Mn) to 391.6Bqkg${ }^{-1}$ (Bauxite) in the fifth company. ${ }^{232}$ Th ranged from $<0.6 \mathrm{Bqkg}^{-1}$ (Fluorspar and $\mathrm{Mn}$ ) to $13.1 \mathrm{Bqkg}^{-1}$ (Calcium aluminates) in the second company; ranged from $<0.6 \mathrm{Bqkg}^{-1}$ (Calcium oxide, Fe-Si-Mn and Fe-Mn) to $11.8 \mathrm{Bqkg}^{-1}$ (Fluorspar) the third company; ranged from $<0.6 \mathrm{Bqkg}^{-1}$ (Si-Mn) to $16.2 \mathrm{Bqkg}^{-1}$ (coke) in the fourth company and ranged from $<0.6 \mathrm{Bqkg}^{-1}$ (Fe-Mnand Dolomite) to $426.9 \mathrm{Bqkg}^{-1}$ (Bauxite) in the fifth company. ${ }^{4} \mathrm{~K}$ ranged from $<3.0 \mathrm{Bqkg}^{-1}$ (coal and lime) to 127.5 $\mathrm{Bqkg}^{-1}$ (Anthracite powder) in the second company; ranged from $<3.0 \mathrm{Bqkg}^{-1}$ (Ca-Si, Calcium oxide, Dolomite and Fe-Si-Mn, lime and Fe-Mn) to 897.6 $\mathrm{Bqkg}^{-1}$ (Fluorspar)the third company;ranged from $<3.0 \mathrm{Bqkg}^{-1}$ (Fluorspar) to $59.2 \mathrm{Bqkg}^{-1}$ (coke) in the fourth company and ranged from $<3.0 \mathrm{Bqkg}^{-1}$ (Fe$\mathrm{Mn}$ ) to $118.9 \mathrm{Bqkg}^{-1}$ (lime) in the fifth company. In all raw materials samples ${ }^{137} \mathrm{Cs}$ is under the detection limit.

Table (1) : Specific activity concentrations (dry weight) of ${ }^{226} \mathrm{Ra},{ }^{232} \mathrm{Th},{ }^{40} \mathrm{~K}$ and ${ }^{137} \mathrm{Cs}$ in soil samples.

\begin{tabular}{|c|c|c|c|c|c|}
\hline \multirow{2}{*}{ Site } & \multirow{2}{*}{ SamplesNo. } & \multicolumn{4}{|c|}{ Activity Concentrations of Soil Samples (Bqkg-1) } \\
\hline & & ${ }^{226} \mathrm{Ra}$ & ${ }^{232} \mathrm{Th}$ & ${ }^{40} K$ & ${ }^{137} \mathrm{CS}$ \\
\hline \multirow{20}{*}{ 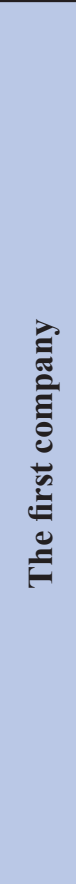 } & S1 & $13.1 \pm 1.5$ & $14.2 \pm 1.5$ & $179.35 \pm 7.8$ & $<0.04$ \\
\hline & S2 & $32.0 \pm 1.3$ & $10.8 \pm 1.0$ & $204.5 \pm 6.3$ & $<0.04$ \\
\hline & S3 & $8.9 \pm 1.3$ & $7.1 \pm 1.02$ & $1578.9 \pm 8.3$ & $<0.04$ \\
\hline & S4 & $9.8 \pm 0.78$ & $7.6 \pm 0.81$ & $119.5 \pm 6.5$ & $<0.04$ \\
\hline & S5 & $26.7 \pm 0.7$ & $9.39 \pm 1.3$ & $54.51 \pm 5.6$ & $<0.04$ \\
\hline & S6 & $6.8 \pm 0.85$ & $7.3 \pm 0.69$ & $165.5 \pm 5.7$ & $<0.04$ \\
\hline & S7 & $15.6 \pm 1.6$ & $11.5 \pm 1.6$ & $151.1 \pm 9.21$ & $<0.04$ \\
\hline & S8 & $10.9 \pm 1.4$ & $10.8 \pm 1.4$ & $188.0 \pm 7.2$ & $<0.04$ \\
\hline & S9 & $11.6 \pm 1.3$ & $7.7 \pm 1.1$ & $175.2 \pm 5.9$ & $<0.04$ \\
\hline & S10 & $15.2 \pm 1.2$ & $7.0 \pm 1.00$ & $169.7 \pm 6.7$ & $<0.04$ \\
\hline & S11 & $13.09 \pm 2.7$ & $11.3 \pm 1.8$ & $187.9 \pm 8.5$ & $<0.04$ \\
\hline & S12 & $41.8 \pm 2.0$ & $6.9 \pm 1.1$ & $60.11 \pm 4.8$ & $<0.04$ \\
\hline & S13 & $65.8 \pm 2.3$ & $11.1 \pm 0.9$ & $91.91 \pm 5.9$ & $<0.04$ \\
\hline & S14 & $15.1 \pm 1.4$ & $7.9 \pm 1.1$ & $216.3 \pm 7.3$ & $<0.04$ \\
\hline & S15 & $50.2 \pm 2.0$ & $9.5 \pm 1.2$ & $93.32 \pm 7.3$ & $<0.04$ \\
\hline & S16 & $45.8 \pm 1.6$ & $11.4 \pm 1.3$ & $132.1 \pm 7.0$ & $<0.04$ \\
\hline & S17 & $22.5 \pm 1.2$ & $12.9 \pm 1.1$ & $206.6 \pm 6.9$ & $<0.04$ \\
\hline & S18 & $26.7 \pm 0.62$ & $7.9 \pm 0.94$ & $12.31 \pm 3.6$ & $<0.04$ \\
\hline & S19 & $227.5 \pm 2.7$ & $19.3 \pm 1.8$ & $90.13 \pm 5.4$ & $<0.04$ \\
\hline & S20 & $12.1 \pm 1.6$ & $6.7 \pm 1.0$ & $191.3 \pm 8.3$ & $<0.04$ \\
\hline
\end{tabular}




\begin{tabular}{|c|c|c|c|c|c|}
\hline \multirow{22}{*}{ 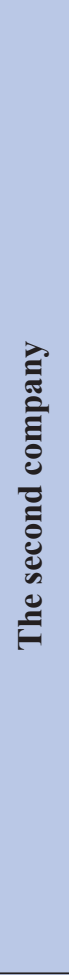 } & S21 & $28.2 \pm 1.3$ & $25.4 \pm 2.0$ & $210.9 \pm 5.9$ & $<0.04$ \\
\hline & $\mathrm{S} 22$ & $25.6 \pm 1.5$ & $14.7 \pm 1.4$ & $193.3 \pm 6.5$ & $<0.04$ \\
\hline & $\mathrm{S} 23$ & $17.8 \pm 1.3$ & $11.9 \pm 1.1$ & $142.6 \pm 5.3$ & $<0.04$ \\
\hline & $\mathrm{S} 24$ & $26.3 \pm 1.7$ & $13.3 \pm 1.6$ & $165.0 \pm 6.4$ & $<0.04$ \\
\hline & $\mathrm{S} 25$ & $20.5 \pm 1.1$ & $11.5 \pm 1.4$ & $113.3 \pm 8.0$ & $<0.04$ \\
\hline & S26 & $27.4 \pm 1.3$ & $17.5 \pm 1.7$ & $114.3 \pm 5.5$ & $<0.04$ \\
\hline & S27 & $21.5 \pm 1.2$ & $13.3 \pm 1.6$ & $184.5 \pm 10$ & $<0.04$ \\
\hline & $\mathrm{S} 28$ & $22.5 \pm 1.6$ & $14.9 \pm 1.5$ & $158.2 \pm 6.3$ & $<0.04$ \\
\hline & S29 & $17.4 \pm 1.5$ & $13.5 \pm 1.3$ & $120.5 \pm 5.5$ & $<0.04$ \\
\hline & S30 & $16.3 \pm 1.6$ & $13.2 \pm 1.6$ & $175.6 \pm 6.2$ & $<0.04$ \\
\hline & S31 & $22.7 \pm 1.4$ & $12.6 \pm 1.5$ & $135.4 \pm 6.7$ & $<0.04$ \\
\hline & S32 & $20.8 \pm 1.3$ & $11.9 \pm 1.5$ & $139.3 \pm 6.3$ & $<0.04$ \\
\hline & S33 & $20.0 \pm 1.1$ & $12.4 \pm 1.9$ & $154.7 \pm 9.1$ & $<0.04$ \\
\hline & S34 & $16.2 \pm 0.9$ & $11.7 \pm 1.6$ & $137.9 \pm 8.8$ & $<0.04$ \\
\hline & S35 & $17.8 \pm 1.0$ & $12.8 \pm 1.3$ & $139.5 \pm 4.6$ & $<0.04$ \\
\hline & S36 & $23.0 \pm 0.85$ & $19.3 \pm 1.5$ & $245.3 \pm 6.4$ & $<0.04$ \\
\hline & S37 & $22.0 \pm 1.5$ & $14.7 \pm 1.2$ & $79.51 \pm 5.6$ & $<0.04$ \\
\hline & S38 & $14.1 \pm 0.72$ & $13.8 \pm 1.3$ & $164.8 \pm 8.3$ & $<0.04$ \\
\hline & S39 & $17.3 \pm 1.0$ & $10.5 \pm 1.2$ & $117.2 \pm 5.3$ & $<0.04$ \\
\hline & $\mathrm{S} 40$ & $22.2 \pm 1.5$ & $11.6 \pm 1.4$ & $136.4 \pm 6.1$ & $<0.04$ \\
\hline & S41 & $11.6 \pm 0.59$ & $6.5 \pm 0.81$ & $16.41 \pm 3.0$ & $<0.04$ \\
\hline & S42 & $12.4 \pm 0.67$ & $12.8 \pm 1.3$ & $149.6 \pm 8.4$ & $<0.04$ \\
\hline \multirow{9}{*}{ 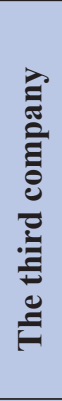 } & S43 & $11.97 \pm 1.1$ & $10.7 \pm 1.3$ & $221.5 \pm 6.3$ & $<0.04$ \\
\hline & S44 & $19.1 \pm 1.25$ & $13.5 \pm 1.52$ & $203.3 \pm 6.5$ & $<0.04$ \\
\hline & S45 & $10.8 \pm 0.91$ & $7.51 \pm 1.16$ & $146.2 \pm 4.8$ & $<0.04$ \\
\hline & S46 & $20.3 \pm 1.59$ & $7.06 \pm 1.43$ & $59.9 \pm 6.42$ & $12.0 \pm 0.69$ \\
\hline & S47 & $12.1 \pm 1.15$ & $13.2 \pm 1.17$ & $170.1 \pm 6.3$ & $0.43 \pm 0.17$ \\
\hline & S48 & $13.65 \pm 1.5$ & $13.3 \pm 1.55$ & $220.2 \pm 6.7$ & $1.71 \pm 0.34$ \\
\hline & S49 & $21.4 \pm 1.27$ & $12.31 \pm 1.8$ & $208.9 \pm 11$ & $<0.04$ \\
\hline & $\mathrm{S} 50$ & $20.2 \pm 0.71$ & $10.5 \pm 1.16$ & $164.8 \pm 5.2$ & $18.6 \pm 0.48$ \\
\hline & S51 & $11.51 \pm 1.1$ & $11.91 \pm 1.2$ & $200.5 \pm 5.5$ & $<0.04$ \\
\hline \multirow{9}{*}{ 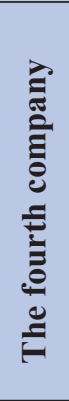 } & S52 & $14.52 \pm 1.2$ & $11.81 \pm 1.4$ & $140.4 \pm 4.9$ & $<0.04$ \\
\hline & S53 & $13.23 \pm 1.3$ & $12.61 \pm 1.3$ & $173.9 \pm 5.5$ & $<0.04$ \\
\hline & S54 & $15.32 \pm 1.2$ & $14.51 \pm 1.4$ & $196.5 \pm 6.3$ & $<0.04$ \\
\hline & S55 & $10.22 \pm 1.0$ & $10.11 \pm 1.3$ & $182.2 \pm 5.7$ & $<0.04$ \\
\hline & S56 & $5.74 \pm 0.48$ & $5.71 \pm 0.99$ & $118.5 \pm 4.2$ & $<0.04$ \\
\hline & S57 & $12.2 \pm 1.13$ & $7.92 \pm 1.21$ & $112.2 \pm 4.7$ & $<0.04$ \\
\hline & S58 & $15.9 \pm 1.31$ & $15.1 \pm 1.40$ & $191.8 \pm 5.9$ & $<0.04$ \\
\hline & S59 & $10.0 \pm 1.00$ & $9.61 \pm 1.30$ & $169.2 \pm 5.8$ & $<0.04$ \\
\hline & S60 & $13.9 \pm 1.23$ & $16.4 \pm 1.30$ & $202.2 \pm 5.7$ & $<0.04$ \\
\hline \multirow{8}{*}{ 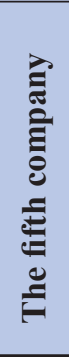 } & S61 & $1.71 \pm 0.74$ & $2.81 \pm 0.80$ & $13.2 \pm 0.90$ & $<0.04$ \\
\hline & S62 & $19.4 \pm 0.82$ & $11.3 \pm 1.49$ & $135.2 \pm 5.8$ & $<0.04$ \\
\hline & S63 & $<0.7$ & $<0.6$ & $4.84 \pm 1.50$ & $<0.04$ \\
\hline & S64 & $2.00 \pm 0.5$ & $1.21 \pm 0.5$ & $3.63 \pm 1.60$ & $<0.04$ \\
\hline & S65 & $15.21 \pm 1.1$ & $9.51 \pm 1.4$ & $99.1 \pm 4.80$ & $<0.04$ \\
\hline & S66 & $15.01 \pm 1.0$ & $8.0 \pm 1.11$ & $103.2 \pm 4.4$ & $<0.04$ \\
\hline & S67 & $12.32 \pm 1.1$ & $6.0 \pm 1.21$ & $87.6 \pm 3.70$ & $<0.04$ \\
\hline & S68 & $25.4 \pm 2.2$ & $<0.6$ & $21.6 \pm 10.3$ & $<0.04$ \\
\hline
\end{tabular}




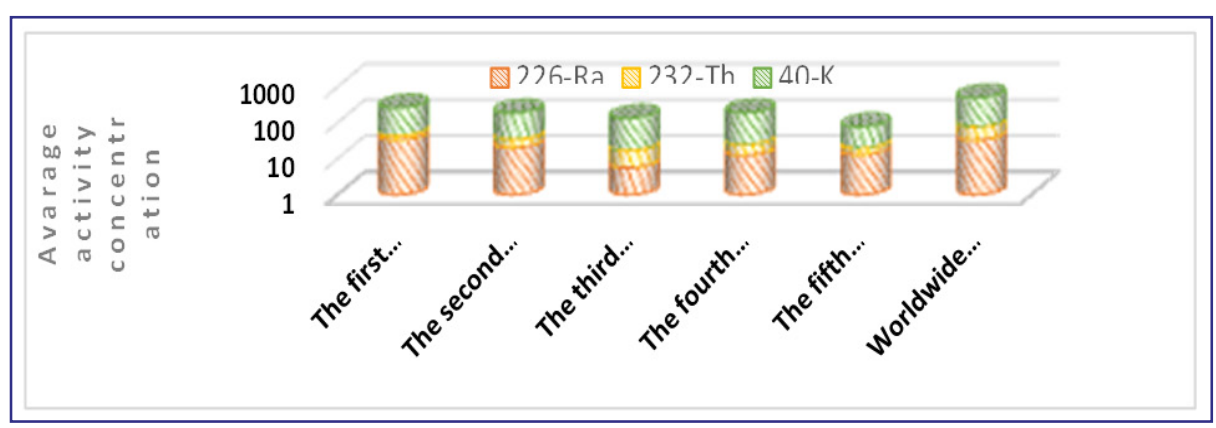

Fig. (2): The average activity concentrations for ${ }^{226} \mathrm{Ra},{ }^{232} \mathrm{Th}$ and ${ }^{40} \mathrm{~K}$ in soil.

Table (2) : Comparison of ${ }^{226} \mathrm{Ra}$ and ${ }^{232} \mathrm{Th}^{40} \mathrm{~K}$ average specific activity of soil samples for various countries.

\begin{tabular}{|c|c|c|c|}
\hline \multirow{2}{*}{ Name of country } & \multicolumn{3}{|c|}{ An average specific activity $\left(B q \mathrm{~kg}^{-1}\right)$} \\
\hline & ${ }^{226} \boldsymbol{R a}$ & ${ }^{232} \mathrm{Th}$ & ${ }^{40} \boldsymbol{K}$ \\
\hline United State $^{*}$ & 40 & 35 & 370 \\
\hline Egypt $^{*}$ & 17 & 18 & 320 \\
\hline China* $^{*}$ & 32 & 41 & 440 \\
\hline India* $^{*}$ & 29 & 64 & 400 \\
\hline Japan $^{*}$ & 33 & 28 & 310 \\
\hline $\operatorname{Iran}^{*}$ & 28 & 22 & 640 \\
\hline Denmark $^{*}$ & 17 & 19 & 460 \\
\hline Belgium* & 26 & 27 & 380 \\
\hline Switzerland $^{*}$ & 40 & 25 & 370 \\
\hline Poland $^{*}$ & 26 & 21 & 410 \\
\hline Romania* & 32 & 38 & 490 \\
\hline Greece $^{*}$ & 25 & 21 & 360 \\
\hline Portugal $^{*}$ & 44 & 51 & 840 \\
\hline Worldwide an average value of ${ }^{* *}$ & 33 & 45 & 412 \\
\hline
\end{tabular}

*(UNSCEAR, 2000)** (UNSCEAR, 2008)

\section{The radiological hazard indices}

The average values of all the studied radiological hazard indices for soil samples are presented in Table 5.The calculated $\mathrm{Ra}_{\text {eq }}, \mathrm{I}_{\gamma}, \mathrm{D}_{\mathrm{r}}$, AEDE, AGED, and ELCR values of the soil samples ranged from (0.37 to $\left.262.0 \mathrm{Bqkg}^{-1}\right),(0.003$ to 1.77$),(0.20$ to $\left.120.5 \mathrm{nGyh}^{-1}\right)\left(0.25\right.$ to $\left.147.8 \mu \mathrm{Svy}^{-1}\right),(0.002$ to 0.81 $\left.\mathrm{mSvy}^{-1}\right)$, and $\left(0.001 \times 10^{-3}\right.$ to $\left.0.517 \times 10^{-3}\right)$ with averages values of $51.0 \mathrm{Bqkg}^{-1}, 0.39,25.5 \mathrm{nGyh}^{-1}, 31.3$ $\mu \mathrm{Svy}^{-1}, 0.16 \mathrm{mSvy}^{-1}$ and $0.11 \times 10^{-3}$ respectively.
The average values of all the studied hazard indices forraw materials are presented in Table 6.The calculated $\mathrm{Ra}_{\mathrm{eq}}, \mathrm{I}_{\gamma}, \mathrm{D}_{\mathrm{r}}, \mathrm{AEDE}$, AGED, and ELCR values of the raw materials ranged from ( 0.50 to $\left.1009.36 \mathrm{Bqkg}^{-1}\right),(0.004$ to 6.9$),\left(0.27\right.$ to $442.7 \mathrm{nGyh}^{-}$ $\left.{ }^{1}\right),\left(0.33\right.$ to $\left.542.9 \mu \mathrm{Svy}^{-1}\right),\left(0.002\right.$ to $\left.3.02 \mathrm{mSvy}^{-1}\right)$ and $\left(0.001 \times 10^{-3}\right.$ to $\left.1.90 \times 10^{-3}\right)$ with averages values of 56.3 $\mathrm{Bqkg}^{-1}, 0.39,25.5 \mathrm{nGyh}^{-1}, 31.2 \mu \mathrm{Svy}^{-1}, 0.18$ $\mathrm{mSvy}^{-1}$ and $0.108 \times 10^{-3}$ respectively. 
Table (3) : Specific activity of ${ }^{226} \mathrm{Ra},{ }^{232} \mathrm{Th},{ }^{40} \mathrm{~K}$ and ${ }^{137} \mathrm{Cs}$ in raw materials.

\begin{tabular}{|c|c|c|c|c|c|}
\hline \multirow{2}{*}{ Site } & \multirow{2}{*}{ Raw Materials } & \multicolumn{4}{|c|}{ Specific activity of raw materials $\left(\mathrm{Bq} \mathrm{kg}^{-1}\right)$} \\
\hline & & ${ }^{226} \boldsymbol{R a}$ & ${ }^{232} \mathrm{Th}$ & ${ }^{40} K$ & ${ }^{137} \mathrm{Cs}$ \\
\hline \multirow{13}{*}{ 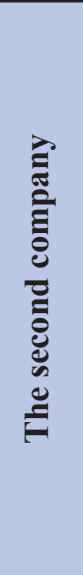 } & $\mathrm{Fe}-\mathrm{Si}$ & $16.8 \pm 1.20$ & $11.4 \pm 2.0$ & $117.9 \pm 6.8$ & $<0.04$ \\
\hline & Fe-Si (lambo) & $5.8 \pm 0.86$ & $4.3 \pm 0.8$ & $30.7 \pm 2.2$ & $<0.04$ \\
\hline & Si-Mn & $2.9 \pm 0.50$ & $1.9 \pm 0.4$ & $25.1 \pm 1.6$ & $<0.04$ \\
\hline & Silicon & $14.2 \pm 1.50$ & $8.7 \pm 1.7$ & $10.8 \pm 3.8$ & $<0.04$ \\
\hline & $\mathrm{Mn}$ & $2.6 \pm 0.58$ & $<0.6$ & $5.6 \pm 1.4$ & $<0.04$ \\
\hline & Calcium aluminates & $21.6 \pm 1.6$ & $13.1 \pm 1.5$ & $56.0 \pm 4.4$ & $<0.04$ \\
\hline & Oxide billets & $13.1 \pm 0.9$ & $11.7 \pm 0.8$ & $6.3 \pm 0.9$ & $<0.04$ \\
\hline & Anthracite powder & $19.1 \pm 1.5$ & $8.93 \pm 1.8$ & $127.5 \pm 6.9$ & $<0.04$ \\
\hline & Dolomite & $49.2 \pm 1.7$ & $3.0 \pm 1.4$ & $48.9 \pm 3.7$ & $<0.04$ \\
\hline & Fluorspar & $85.9 \pm 1.6$ & $<0.6$ & $8.6 \pm 3.8$ & $<0.04$ \\
\hline & Coal & $8.5 \pm 1.6$ & $4.4 \pm 0.9$ & $<3.0$ & $<0.04$ \\
\hline & Limestone & $13.5 \pm 1.4$ & $4.1 \pm 1.2$ & $<3.0$ & $<0.04$ \\
\hline & main ore in steel & $10.3 \pm 0.8$ & $7.5 \pm 0.8$ & $61.9 \pm 2.6$ & $<0.04$ \\
\hline \multirow{12}{*}{ 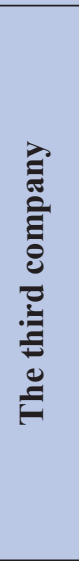 } & $\mathrm{Ca}-\mathrm{Si}$ & $16.2 \pm 0.8$ & $4.0 \pm 0.7$ & $<3.0$ & $<0.04$ \\
\hline & $\mathrm{Fe}-\mathrm{Si}$ & $2.3 \pm 0.5$ & $1.9 \pm 0.7$ & $3.5 \pm 1.8$ & $<0.04$ \\
\hline & Fe-Mn & $<0.7$ & $<0.6$ & $<3.0$ & $<0.04$ \\
\hline & $\mathrm{Fe}-\mathrm{Si}-\mathrm{Mn}$ & $<0.7$ & $<0.6$ & $<3.0$ & $<0.04$ \\
\hline & $\mathrm{CaO}$ & $46.7 \pm 1.6$ & $<0.6$ & $<3.0$ & $<0.04$ \\
\hline & Dolomite & $34.4 \pm 1.6$ & $1.2 \pm 0.5$ & $<3.0$ & $<0.04$ \\
\hline & Fluorspar & $53.7 \pm 1.8$ & $11.8 \pm 1.6$ & $897.6 \pm 10$ & $<0.04$ \\
\hline & Coke & $11.9 \pm 1.3$ & $6.5 \pm 1.5$ & $36.2 \pm 8.4$ & $<0.04$ \\
\hline & Limestone & $5.3 \pm 0.8$ & $<0.6$ & $<3.0$ & $<0.04$ \\
\hline & carbon (1-4)mm & $14.5 \pm 1.9$ & $9.3 \pm 1.9$ & $81.2 \pm 7.2$ & $<0.04$ \\
\hline & carbon $(15-40) \mathrm{mm}$ & $3.5 \pm 1.1$ & $3.7 \pm 1.6$ & $14.2 \pm 6.2$ & $<0.04$ \\
\hline & $\begin{array}{l}\text { powder release from } \\
\text { scrap }\end{array}$ & $17.3 \pm 1.2$ & $6.6 \pm 1.2$ & $18.1 \pm 4.3$ & $<0.04$ \\
\hline \multirow{8}{*}{ 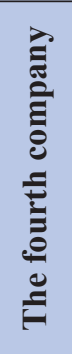 } & Fe-Si (imported) & $13.7 \pm 1.0$ & $9.8 \pm 1.0$ & $6.1 \pm 2.8$ & $<0.04$ \\
\hline & Fe-Si (local) & $4.5 \pm 0.8$ & $3.5 \pm 0.8$ & $7.8 \pm 2.6$ & $<0.04$ \\
\hline & Si-Mn & $<0.7$ & $<0.6$ & $6.5 \pm 1.5$ & $<0.04$ \\
\hline & Dolomite & $54.2 \pm 1.7$ & $1.8 \pm 0.9$ & $16.3 \pm 3.6$ & $<0.04$ \\
\hline & Olivine sand filter & $<0.7$ & $2.0 \pm 0.8$ & $10.9 \pm 3.6$ & $<0.04$ \\
\hline & Fluorspar & $84.0 \pm 1.6$ & $3.5 \pm 1.2$ & $<3.0$ & $<0.04$ \\
\hline & Limestone & $36.8 \pm 1.4$ & $1.4 \pm 0.9$ & $18.7 \pm 3.9$ & $<0.04$ \\
\hline & Coke & $13.7 \pm 1.6$ & $16.2 \pm 1.9$ & $59.2 \pm 7.2$ & $<0.04$ \\
\hline \multirow{9}{*}{ 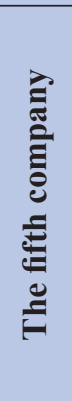 } & Si-Mn & $11.4 \pm 1.1$ & $6.7 \pm 1.2$ & $108.9 \pm 4.8$ & $<0.04$ \\
\hline & $\mathrm{Fe}-\mathrm{Si}$ & $5.2 \pm 0.8$ & $7.4 \pm 0.9$ & $14.3 \pm 2.6$ & $<0.04$ \\
\hline & Fe-Mn & $<0.7$ & $<0.6$ & $<3.0$ & $<0.04$ \\
\hline & Mn high carbon & $14.8 \pm 1.1$ & $6.4 \pm 2.4$ & $92.6 \pm 10$ & $<0.04$ \\
\hline & Dolomite & $54.2 \pm 1.9$ & $<0.6$ & $21.5 \pm 4.8$ & $<0.04$ \\
\hline & Limestone & $20.2 \pm 1.1$ & $11.1 \pm 1.4$ & $118.9 \pm 4.9$ & $<0.04$ \\
\hline & Fluorspar & $17.2 \pm 1.0$ & $11.5 \pm 1.3$ & $117.7 \pm 4.8$ & $<0.04$ \\
\hline & Bauxite & $391.6 \pm 3.0$ & $426.9 \pm 3.1$ & $94.8 \pm 8.8$ & $<0.04$ \\
\hline & Coke & $18.7 \pm 1.8$ & $10.8 \pm 1.8$ & $76.1 \pm 7.0$ & $<0.04$ \\
\hline
\end{tabular}


Table (4) : Specific activity of ${ }^{226} \mathrm{Ra},{ }^{232} \mathrm{Th},{ }^{40} \mathrm{~K}$ and ${ }^{137} \mathrm{Cs}$ in waste samples.

\begin{tabular}{|c|c|c|c|c|}
\hline \multirow{2}{*}{ Waste samples } & \multicolumn{4}{|c|}{ Specific activity $\left(\right.$ Bqkg $\left.^{-1}\right)$} \\
\cline { 2 - 5 } & ${ }^{226} \boldsymbol{R} \boldsymbol{a}$ & ${ }^{232} \boldsymbol{T h}$ & ${ }^{40} \boldsymbol{K}$ & ${ }^{137} \boldsymbol{C}$ \\
\hline Slag (the second company ) & $50.9 \pm 1.2$ & $14.6 \pm 1.7$ & $9.3 \pm 3.4$ & $<0.04$ \\
\hline dust beside DRP (the second company) & $13.0 \pm 1.0$ & $6.7 \pm 0.9$ & $10.1 \pm 2.9$ & $<0.04$ \\
\hline brick from EAF (the third company ) & $82.6 \pm 1.6$ & $85.1 \pm 2.2$ & $129.5 \pm 5.5$ & $4.12 \pm 0.2$ \\
\hline Slag (the third company ) & $17.8 \pm 0.9$ & $5.3 \pm 1.1$ & $15.3 \pm 3.3$ & $<0.04$ \\
\hline Scale (the fourth company ) & $4.11 \pm 0.7$ & $2.8 \pm 0.7$ & $7.6 \pm 2.3$ & $<0.04$ \\
\hline Slag (the fourth company ) & $18.0 \pm 1.2$ & $7.2 \pm 0.8$ & $10.3 \pm 2.9$ & $<0.04$ \\
\hline EAF dust (the fourth company ) & $13.5 \pm 2.4$ & $7.0 \pm 2.7$ & $656.7 \pm 14$ & $1.5 \pm 0.6$ \\
\hline Scale (the fifth company ) & $<0.7$ & $1.5 \pm 0.1$ & $1.2 \pm 0.1$ & $<0.04$ \\
\hline
\end{tabular}

Table (5) : The average of radiation hazard parameters for soil samples.

\begin{tabular}{|c|c|c|c|c|c|c|c|c|c|c|c|c|c|c|c|c|c|c|}
\hline \multirow{2}{*}{ Site } & \multicolumn{3}{|c|}{$R a_{e q}\left(B q k g^{-1}\right)$} & \multicolumn{3}{|c|}{$I_{\gamma}$} & \multicolumn{3}{|c|}{$D\left(n G y h^{-1}\right)$} & \multicolumn{3}{|c|}{$\begin{array}{l}A E D E \\
\left(\mu S v y^{1}\right)\end{array}$} & \multicolumn{3}{|c|}{$\begin{array}{c}A G E D \\
\left(m S v y^{-1}\right)\end{array}$} & \multicolumn{3}{|c|}{$E L C R \times 10^{-3}$} \\
\hline & $\operatorname{Min}$ & $\operatorname{Max}$ & Aver: & Min & $\operatorname{Max}$ & Aver: & Min & $\operatorname{Max}$ & Aver: & Min & $\operatorname{Max}$ & Aver: & Min & $\operatorname{Max}$ & Aver. & Min & Max & Aver: \\
\hline $\begin{array}{c}\text { The first } \\
\text { Co. }\end{array}$ & 29.8 & 262.0 & 64.2 & 0.22 & 1.70 & 0.47 & 14.1 & 120.5 & 30.3 & 17.2 & 147.8 & 37.2 & 0.10 & 0.8 & 0.21 & 0.06 & 0.51 & 0.13 \\
\hline $\begin{array}{c}\text { The } \\
\text { second } \\
\text { Co. }\end{array}$ & 22.1 & 80.7 & 50.0 & 0.15 & 0.58 & 0.36 & 9.9 & 37.1 & 23.2 & 12.2 & 45.5 & 28.5 & 0.06 & 0.26 & 0.16 & 0.04 & 0.16 & 0.10 \\
\hline $\begin{array}{c}\text { The third } \\
\text { Co. }\end{array}$ & 32.7 & 55.0 & 45.2 & 0.24 & 0.40 & 0.33 & 15.6 & 26.0 & 21.3 & 19.1 & 31.9 & 26.1 & 0.11 & 0.18 & 0.15 & 0.06 & 0.11 & 0.09 \\
\hline $\begin{array}{c}\text { The forth } \\
\text { Co. }\end{array}$ & 22.9 & 52.9 & 41.5 & 0.17 & 0.39 & 0.31 & 11.0 & 24.7 & 19.5 & 13.5 & 30.3 & 23.9 & 0.07 & 0.17 & 0.14 & 0.04 & 0.10 & 0.08 \\
\hline $\begin{array}{c}\text { The fifth } \\
\text { Co. }\end{array}$ & 0.3 & 45.9 & 22.8 & 0.003 & 0.33 & 0.16 & 0.2 & 21.4 & 10.6 & 0.25 & 26.2 & 13.0 & 0.002 & 0.15 & 0.07 & 0.001 & 0.09 & 0.05 \\
\hline
\end{tabular}


Table (6) : Radiation Hazard Parameters for raw materials Samples.

\begin{tabular}{|c|c|c|c|c|c|c|c|}
\hline SITE & Raw materials & $\begin{array}{c}R a_{e q} \\
\left(B q g^{-1}\right)\end{array}$ & $I_{\gamma}$ & $\begin{array}{c}D \\
\left(n G y h^{-1}\right)\end{array}$ & $\begin{array}{c}A E D E \\
\left(\mu S v y^{-1}\right)\end{array}$ & $\begin{array}{c}\text { AGED } \\
\left(m S v y^{-1}\right)\end{array}$ & $\begin{array}{r}E L C R \\
\times 10^{-3}\end{array}$ \\
\hline \multirow{13}{*}{ 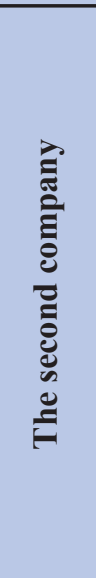 } & $\mathrm{Fe}-\mathrm{Si}$ & 42.18 & 0.301 & 19.56 & 23.99 & 0.137 & 0.084 \\
\hline & Fe-Si (lambo) & 14.31 & 0.102 & 6.56 & 8.15 & 0.046 & 0.028 \\
\hline & Si-Mn & 7.54 & 0.055 & 3.53 & 4.37 & 0.025 & 0.015 \\
\hline & Silicon & 27.47 & 0.188 & 12.27 & 15.04 & 0.084 & 0.053 \\
\hline & $\mathrm{Mn}$ & 3.03 & 0.021 & 1.43 & 1.76 & 0.010 & 0.006 \\
\hline & Calcium aluminates & 44.95 & 0.314 & 20.23 & 24.80 & 0.139 & 0.087 \\
\hline & Oxide billets & 30.32 & 0.208 & 13.38 & 16.40 & 0.091 & 0.057 \\
\hline & Anthracite powder & 41.64 & 0.301 & 19.52 & 23.92 & 0.136 & 0.084 \\
\hline & Dolomite & 57.25 & 0.391 & 26.58 & 32.60 & 0.180 & 0.114 \\
\hline & Fluorspar & 86.56 & 0.578 & 40.04 & 49.11 & 0.268 & 0.172 \\
\hline & Coal & 14.79 & 0.101 & 6.58 & 8.08 & 0.045 & 0.028 \\
\hline & Limestone & 19.36 & 0.131 & 8.71 & 10.69 & 0.059 & 0.037 \\
\hline & main ore in steel & 25.79 & 0.184 & 11.87 & 14.56 & 0.083 & 0.051 \\
\hline \multirow{12}{*}{ 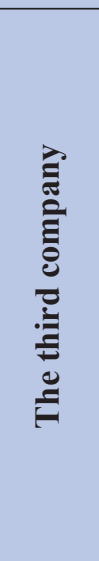 } & $\mathrm{Ca}-\mathrm{Si}$ & 21.92 & 0.148 & 9.90 & 12.14 & 0.067 & 0.042 \\
\hline & $\mathrm{Fe}-\mathrm{Si}$ & 5.37 & 0.037 & 2.39 & 2.93 & 0.016 & 0.010 \\
\hline & $\mathrm{Fe}-\mathrm{Mn}$ & ND & ND & ND & ND & ND & ND \\
\hline & $\mathrm{Fe}-\mathrm{Si}-\mathrm{Mn}$ & ND & ND & ND & ND & ND & ND \\
\hline & $\mathrm{CaO}$ & 46.73 & 0.311 & 21.58 & 26.46 & 0.144 & 0.093 \\
\hline & Dolomite & 36.22 & 0.242 & 16.66 & 20.43 & 0.112 & 0.072 \\
\hline & Fluorspar & 139.60 & 1.074 & 69.37 & 85.07 & 0.497 & 0.298 \\
\hline & Coke & 23.98 & 0.168 & 10.93 & 13.41 & 0.075 & 0.047 \\
\hline & Limestone & 5.32 & 0.035 & 2.45 & 3.0 & 0.016 & 0.011 \\
\hline & carbon (1-4) mm & 34.04 & 0.243 & 15.70 & 19.26 & 0.109 & 0.067 \\
\hline & carbon $(15-40) \mathrm{mm}$ & 9.88 & 0.070 & 4.44 & 5.45 & 0.031 & 0.019 \\
\hline & $\begin{array}{c}\text { powder release from } \\
\text { scrap }\end{array}$ & 28.13 & 0.193 & 12.73 & 15.62 & 0.087 & 0.055 \\
\hline \multirow{8}{*}{ 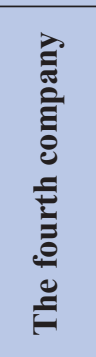 } & Fe-Si (imported) & 28.18 & 0.193 & 12.50 & 15.33 & 0.085 & 0.054 \\
\hline & $\mathrm{Fe}-\mathrm{Si}$ (local) & 10.10 & 0.070 & 4.52 & 5.54 & 0.031 & 0.019 \\
\hline & Si-Mn & 0.50 & 0.004 & 0.27 & 0.33 & 0.002 & 0.001 \\
\hline & Dolomite & 58.02 & 0.390 & 26.81 & 32.88 & 0.180 & 0.115 \\
\hline & Olivine sand filter & 3.69 & 0.027 & 1.66 & 2.04 & 0.012 & 0.007 \\
\hline & Fluorspar & 89.01 & 0.595 & 40.92 & 50.19 & 0.274 & 0.176 \\
\hline & Limestone & 40.24 & 0.271 & 18.63 & 22.84 & 0.125 & 0.080 \\
\hline & Coke & 41.42 & 0.292 & 18.58 & 22.79 & 0.129 & 0.080 \\
\hline \multirow{9}{*}{ 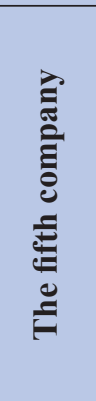 } & Si-Mn & 29.37 & 0.216 & 13.85 & 16.99 & 0.097 & 0.059 \\
\hline & $\mathrm{Fe}-\mathrm{Si}$ & 16.88 & 0.118 & 7.47 & 9.16 & 0.051 & 0.032 \\
\hline & Fe-Mn & ND & ND & ND & ND & ND & ND \\
\hline & Mn high carbon & 31.08 & 0.224 & 14.50 & 17.86 & 0.102 & 0.063 \\
\hline & Dolomite & 55.85 & 0.376 & 25.90 & 31.81 & 0.174 & 0.111 \\
\hline & Limestone & 45.23 & 0.325 & 20.90 & 25.75 & 0.146 & 0.090 \\
\hline & Fluorspar & 42.70 & 0.308 & 19.80 & 24.28 & 0.138 & 0.085 \\
\hline & Bauxite & 1009.30 & 6.942 & 442.70 & 542.95 & 3.024 & 1.900 \\
\hline & Coke & 40.00 & 0.283 & 18.34 & 22.49 & 0.127 & 0.079 \\
\hline
\end{tabular}




\section{Heavy Metals analysis}

The concentration of heavy metals (ppm) for some of the collected soil samples is presented in Table 7.

Concentration of $\mathrm{Cd}, \mathrm{Cr}, \mathrm{Cu}, \mathrm{Fe}, \mathrm{Mn}, \mathrm{Ni}, \mathrm{Pb}$, $\mathrm{Zn}$, and As ranged from (0.037 to 56.5$),(2.26$ to
922.6), ( 3.9 to 774.2$)$, ( 5184.2 to 99669.2$),(94.1$ to 17299.1$),(4.1$ to 129.5$),(6.0$ to 1322.6$),(34.2$ to $2716.1),(0.03$ to 22.3$) \mathrm{ppm}$, with an average values of $4.4,127.1,87.3,29034.0,2995.1,19.1,113.1$, 588.5 , and 5.5 ppm respectively.

Table (7) : Heavy metals concentrations (ppm) for soil samples.

\begin{tabular}{|c|c|c|c|c|c|c|c|c|c|c|}
\hline Site & $\begin{array}{c}\text { Sample } \\
\text { No. }\end{array}$ & $C d$ & $\mathrm{Cr}$ & Cu & $\mathrm{Fe}$ & Mn & $N i$ & $P b$ & $Z n$ & As \\
\hline \multirow{5}{*}{ 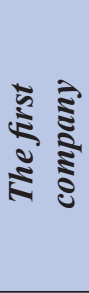 } & $S 2$ & ND & 29.15 & 26.25 & 11389.3 & 1229.8 & 9.8625 & 11.99 & 100.37 & 0.97 \\
\hline & $S 5$ & ND & 303.2 & 32.15 & 53594.3 & 17299.1 & 9.6125 & 13.24 & 156.09 & 2.05 \\
\hline & $S 13$ & 0.513 & 139.0 & 6.50 & 74719.3 & 10846.6 & 12.0875 & 15.79 & 229.62 & 19.03 \\
\hline & $S 14$ & 0.538 & 2.9 & 6.62 & 61444.3 & 10386.6 & 15.7125 & 19.04 & 441.64 & 12.08 \\
\hline & $S 16$ & 4.638 & 106.7 & 24.25 & 58844.3 & 8936.6 & 12.8625 & 75.04 & 2297.40 & 18.45 \\
\hline \multirow{5}{*}{ 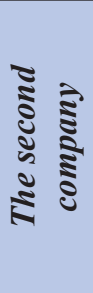 } & $S 22$ & 0.638 & 49.80 & 49.53 & 18729.3 & 439.07 & 15.76 & 40.49 & 403.39 & 2.65 \\
\hline & $S 25$ & 0.213 & 26.73 & 23.70 & 6176.8 & 542.07 & 8.04 & 16.42 & 140.92 & 22.33 \\
\hline & S34 & 0.313 & 31.13 & 27.50 & 8479.3 & 273.57 & 8.31 & 28.59 & 160.67 & 3.12 \\
\hline & $S 36$ & ND & 108.48 & ND & 99669.3 & 315.32 & 17.41 & 40.74 & 49.96 & ND \\
\hline & $S 37$ & 1.863 & 4.65 & 60.50 & 44269.3 & 1598.60 & 23.29 & 100.70 & 813.64 & 0.025 \\
\hline \multirow{4}{*}{ 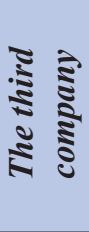 } & $S 44$ & 2.863 & 102.0 & 89.25 & 17336.8 & 960.32 & 27.04 & 162.9 & 981.89 & 7.675 \\
\hline & $S 45$ & 3.463 & 147.3 & 398.30 & 23869.3 & 1318.80 & 40.66 & 148.5 & 886.39 & 3.975 \\
\hline & $S 49$ & 1.363 & 65.05 & 75.15 & 15151.8 & 541.32 & 17.99 & 67.67 & 624.39 & 0.925 \\
\hline & S50 & 56.58 & 922.65 & 774.25 & 61694.3 & 5389.10 & 129.50 & 1322.70 & 2716.10 & 3.325 \\
\hline \multirow{4}{*}{ 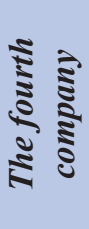 } & $S 52$ & 4.633 & 530.10 & 112.10 & 32119.3 & 3849.10 & 24.34 & 186.2 & 1280.40 & 1.285 \\
\hline & $S 54$ & 1.193 & 40.65 & 24.68 & 9081.8 & 219.79 & 9.27 & 46.9 & 272.89 & 3.548 \\
\hline & S56 & 2.138 & 67.38 & 38.03 & 8264.2 & 722.32 & 7.98 & 91.0 & 700.39 & 0.550 \\
\hline & $S 59$ & 1.280 & 57.03 & 40.55 & 9294.2 & 483.82 & 10.12 & 66.1 & 443.14 & 0.715 \\
\hline \multirow{9}{*}{ 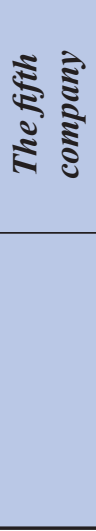 } & $S 61$ & 0.313 & 2.27 & 8.24 & 6829.2 & 145.17 & 4.78 & 6.65 & 43.21 & 1.273 \\
\hline & $S 62$ & 0.413 & 23.05 & 8.20 & 5744.2 & 163.67 & 4.88 & 13.87 & 110.19 & 1.325 \\
\hline & 563 & 0.038 & 18.10 & 4.38 & 5184.2 & 94.16 & 5.51 & 6.02 & 47.27 & 1.250 \\
\hline & 567 & 0.163 & 19.28 & 3.98 & 6876.7 & 138.54 & 4.08 & 6.62 & 46.94 & 1.875 \\
\hline & Max & 56.58 & 922.6 & 774.2 & 99669.2 & 17299.1 & 129.51 & 1322.69 & 2716.14 & 22.320 \\
\hline & Min & 0.04 & 2.26 & 3.97 & 5184.2 & 94.16 & 4.08 & 6.02 & 43.21 & 0.025 \\
\hline & Average & 4.40 & 127.10 & 87.30 & 29034.0 & 2995.1 & 19.1 & 113.10 & 588.50 & 5.500 \\
\hline & B & 0.15 & 100 & 55 & 56300 & 850 & 75 & 12.50 & 70 & 1.500 \\
\hline & \multicolumn{10}{|c|}{ B: is the average concentrations of elements in the Earth's crust } \\
\hline
\end{tabular}




\section{Assessment of heavy metal pollution}

The $C_{f}^{i}, \mathrm{C}_{\mathrm{deg}}$, PLI and PLI for zonevalues of the heavy metals in soil samples are presented in Table 8. Soil at the first company was classified as very high contamination with $\mathrm{Cd}, \mathrm{Mn}, \mathrm{Zn}$ and As (average $\mathrm{C}_{\mathrm{f}}^{\mathrm{i}}$ $=12.6,11.4,9.2$ and 7.0 respectively), moderate contamination with $\mathrm{Cr}$ and $\mathrm{Pb}$ (average $\mathrm{C}_{\mathrm{f}}^{\mathrm{i}}=1.1$ and 2.2 respectively) and low contamination with $\mathrm{Cu}, \mathrm{Fe}$ and $\mathrm{Ni}$ (average $\mathrm{C}_{\mathrm{f}}^{\mathrm{i}}=0.34,0.92$ and 0.1 respectively). Soil at the second company was classified as considerable contamination with $\mathrm{Cd}, \mathrm{Pb}, \mathrm{Zn}$ and As (average $\mathrm{C}_{\mathrm{f}}^{\mathrm{i}}=5.0,3.7,4.4$ and 4.6 respectively) and low contamination with $\mathrm{Cr}, \mathrm{Cu}, \mathrm{Fe}, \mathrm{Mn}$ and $\mathrm{Ni}$ (average $\mathrm{C}_{\mathrm{f}}^{\mathrm{i}}=$ $0.4,0.7,0.6,0.7$ and 0.1 respectively).

Table (8): The values of the heavy metals $C_{f}^{i} C_{d e g}$ PLI and PLI for zone and in soil samples.

\begin{tabular}{|c|c|c|c|c|c|c|c|c|c|c|c|c|c|}
\hline \multicolumn{11}{|c|}{ Contamination Factors $\left(C_{f}^{i}\right)$} & \multirow{2}{*}{$\mathbf{C}_{\mathrm{deg}}$} & \multirow[t]{2}{*}{ PLI } & \multirow{2}{*}{$\begin{array}{l}\text { PLI for } \\
\text { Zone }\end{array}$} \\
\hline Site & $\begin{array}{c}\text { Sample } \\
\text { No. }\end{array}$ & $C d$ & $\mathrm{Cr}$ & $C u$ & $\mathrm{Fe}$ & $M n$ & $\mathrm{Ni}$ & $P b$ & $Z n$ & As & & & \\
\hline \multirow{6}{*}{ 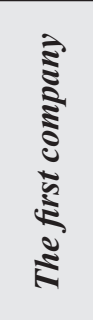 } & $S 2$ & - & 0.29 & 0.48 & 0.2 & 1.45 & 0.13 & 0.98 & 1.43 & 0.65 & 5.62 & 0.51 & \multirow{6}{*}{1.26} \\
\hline & $S 5$ & - & 3.03 & 0.58 & 0.95 & 20.4 & 0.13 & 1.09 & 2.23 & 1.37 & 29.7 & 1.0 & \\
\hline & $S 13$ & 3.42 & 1.39 & 0.12 & 1.33 & 12.8 & 0.16 & 1.29 & 3.28 & 12.6 & 36.4 & 1.63 & \\
\hline & S14 & 3.58 & 0.03 & 0.12 & 1.09 & 12.2 & 0.21 & 1.56 & 6.31 & 8.05 & 33.1 & 1.12 & \\
\hline & $S 16$ & 30.9 & 1.07 & 0.44 & 1.05 & 10.5 & 0.17 & 6.15 & 32.8 & 12.3 & 95.4 & 3.44 & \\
\hline & Average & 12.6 & 1.16 & 0.35 & 0.92 & 11.5 & 0.16 & 2.2 & 9.2 & 7.0 & 40.1 & 1.5 & \\
\hline \multirow{6}{*}{ 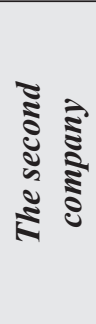 } & $S 22$ & 4.25 & 0.5 & 0.9 & 0.33 & 0.52 & 0.21 & 3.32 & 5.76 & 1.77 & 17.5 & 1.1 & \multirow{6}{*}{0.83} \\
\hline & $S 25$ & 1.42 & 0.27 & 0.43 & 0.11 & 0.64 & 0.11 & 1.35 & 2.01 & 14.8 & 21.2 & 0.72 & \\
\hline & S34 & 2.08 & 0.31 & 0.5 & 0.15 & 0.32 & 0.11 & 2.34 & 2.3 & 2.08 & 10.2 & 0.65 & \\
\hline & $S 36$ & - & 1.08 & - & 1.77 & 0.37 & 0.23 & 3.34 & 0.71 & - & 7.51 & 0.85 & \\
\hline & S37 & 12.4 & 0.05 & 1.1 & 0.79 & 1.88 & 0.31 & 8.26 & 11.6 & 0.02 & 36.4 & 0.92 & \\
\hline & Average & 5.0 & 0.44 & 0.73 & 0.63 & 0.75 & 0.19 & 3.7 & 4.5 & 4.6 & 18.5 & 0.85 & \\
\hline \multirow{5}{*}{ 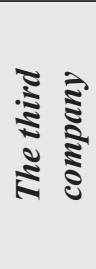 } & $S 44$ & 19.0 & 1.02 & 1.62 & 0.31 & 1.13 & 0.36 & 13.4 & 14.0 & 5.12 & 56.0 & 2.5 & \multirow{5}{*}{3.34} \\
\hline & $S 45$ & 23.0 & 1.47 & 7.24 & 0.42 & 1.55 & 0.54 & 12.2 & 12.6 & 2.65 & 61.8 & 3.21 & \\
\hline & $S 49$ & 9.08 & 0.65 & 1.37 & 0.27 & 0.64 & 0.24 & 5.55 & 8.92 & 0.62 & 27.3 & 1.29 & \\
\hline & $S 50$ & 377 & 9.2 & 14.0 & 1.1 & 6.3 & 1.73 & 108 & 38.8 & 2.22 & 559 & 12.0 & \\
\hline & Average & 107.1 & 3.1 & 6.1 & 0.52 & 2.4 & 0.72 & 34.9 & 18.6 & 2.6 & 176 & 4.7 & \\
\hline \multirow{5}{*}{ 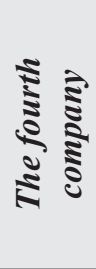 } & S52 & 30.88 & 5.3 & 2.04 & 0.57 & 4.53 & 0.32 & 15.2 & 18.2 & 0.86 & 78.0 & 3.44 & \multirow{5}{*}{1.33} \\
\hline & $S 54$ & 7.95 & 0.41 & 0.45 & 0.16 & 0.26 & 0.12 & 3.85 & 3.9 & 2.3 & 19.4 & 0.86 & \\
\hline & $S 56$ & 14.25 & 0.67 & 0.69 & 0.15 & 0.85 & 0.11 & 7.46 & 10.0 & 0.37 & 34.5 & 1.1 & \\
\hline & $S 59$ & 8.53 & 0.57 & 0.74 & 0.17 & 0.57 & 0.13 & 5.42 & 6.33 & 0.48 & 22.9 & 0.97 & \\
\hline & Average & 15.4 & 1.7 & 0.98 & 0.26 & 1.5 & 0.17 & 8.0 & 9.6 & 1.02 & 38.7 & 1.5 & \\
\hline \multirow{5}{*}{$\begin{array}{l}\text { है } \\
\text { है } \\
\text { है }\end{array}$} & $S 61$ & 2.08 & 0.02 & 0.15 & 0.12 & 0.17 & 0.06 & 0.55 & 0.62 & 0.85 & 4.62 & 0.24 & \multirow{5}{*}{0.26} \\
\hline & $S 62$ & 2.75 & 0.23 & 0.15 & 0.1 & 0.19 & 0.07 & 1.14 & 1.57 & 0.88 & 7.08 & 0.39 & \\
\hline & $S 63$ & 0.25 & 0.18 & 0.08 & 0.09 & 0.11 & 0.07 & 0.49 & 0.68 & 0.83 & 2.79 & 0.21 & \\
\hline & 567 & 1.08 & 0.19 & 0.07 & 0.12 & 0.16 & 0.05 & 0.54 & 0.67 & 1.25 & 4.15 & 0.27 & \\
\hline & Average & 1.5 & 0.16 & 0.11 & 0.11 & 0.16 & 0.06 & 0.68 & 0.88 & 0.95 & 4.6 & 0.27 & \\
\hline
\end{tabular}


Soil at the third company was classified as very high contamination with $\mathrm{Cd}, \mathrm{Cu}, \mathrm{Pb}$ and $\mathrm{Zn}$ (average $C_{f}^{i}=107,6.0,34.8$ and 18.6 respectively), considerable contamination with $\mathrm{Cr}$ (average $\mathrm{C}_{\mathrm{f}}^{\mathrm{i}}=3.0$ ), moderate contamination with $\mathrm{Mn}$ and As (average $\mathrm{C}_{\mathrm{f}}^{\mathrm{i}}=2.4$ and 2.6 respectively) and low contamination with $\mathrm{Fe}$ and $\mathrm{Ni}$ (average $\mathrm{C}_{\mathrm{f}}^{\mathrm{i}}=0.5$ and 0.7 respectively). Soil atthe fourth company was classified as very high contamination with $\mathrm{Cd}, \mathrm{Pb}$ and $\mathrm{Zn}$ (average $\mathrm{C}_{\mathrm{f}}^{\mathrm{i}}$ $=15.4,7.9$ and 9.6 respectively), moderate contamination with $\mathrm{Cr}, \mathrm{Mn}$ and $\mathrm{As}$ (average $\mathrm{C}_{\mathrm{f}}^{\mathrm{i}}=1.7,1.5$ and 1.0 respectively) and low contamination with $\mathrm{Cu}, \mathrm{Fe}$ and $\mathrm{Ni}$ (average $\mathrm{C}_{\mathrm{f}}^{\mathrm{i}}=0.9,0.2$ and 0.17 respectively). Soil at the fifth company was classified as moderate contamination with $\mathrm{Cd}$ (average $\mathrm{C}_{\mathrm{f}}^{\mathrm{i}}=1.5$ ) and low contamination with other metals.

The first company, the second company, the third company, the fourth company, and the fifth company have $\mathrm{C}_{\mathrm{deg}}$ values ranged from (5.62 to 95.4), (7.51 to 36.4$),(27.3$ to 559$),(19.4$ to 78.0$)$ and (2.79 to 7.08 ), with an average values of $40.1,18.5,176.1$, 38.7 and 4.6 respectively.

Thefirst company, the second company, the third company, the fourth company, and the fifth company, have PLI values ranged from (0.5 to 3.4), (0.65 to 1.1$),(1.29$ to 12.0$),(0.86$ to 3.4$)$ and $(0.21$ to 0.39 ), with an average values of $1.5,0.85,4.7,1.5$ and 0.27 respectively. The studied areas are divided into five zones, first zone contains the first companysites, second zone contains the second company sites, third zone contains the third company sites,fourth zone contains the fourth company sites and fifth zone contains the fifth company sites. The PLI for the first, second, third, fourth and fifth zones were calculated according to Eq.11 and were estimated to be $1.26,0.83,3.3,1.3$ and 0.26 respectively.

\section{DISSCUSSION}

\section{Activity Concentrations}

The radionuclide contents in all soil samples are lower than worldwide average values $(33,45$ and 412) $\mathrm{Bqkg}^{-1}$ for ${ }^{226} \mathrm{Ra},{ }^{232} \mathrm{Th}$ and ${ }^{40} \mathrm{~K}$ respectively (UNSCEAR, 2008). Except some soil samples around the first company have higher concentrations for ${ }^{226} \mathrm{Ra}$ and ${ }^{40} \mathrm{~K}$ than worldwide average values, this may be attributed to that the contamination of the area during transportation of waste to the storage area, where waste (blast furnace slag) of this companyhas elevated activity concentration of ${ }^{226} \mathrm{Ra}$ (551.7 $\mathrm{Bqkg}^{-1}$ ) as reported by Bakr (2004).

The activity concentrations of ${ }^{137} \mathrm{Cs}$ in all soil samples are under the detection limits except soil sample S50 was collected near to EAF of the third company also soil samples S47 and S48 lies beside company wall have ${ }^{137} \mathrm{Cs}$, that may be related to contamination of soil by EAFD which transported by air and deposited into the soil. The presence of ${ }^{137} \mathrm{Cs}$ in EAFD may be related to the residues of material that were used in technological possess and nuclear tests in the past and were recycled as scrap in EAF. Also, radiological accidents must be taken in the consideration for example, in May $1998 ;{ }^{137} \mathrm{Cs}$ source was accidentally melted in a steel factory in Spain (Bakr, 2004)

The average activity concentrations for ${ }^{226} \mathrm{Ra}$, ${ }^{232} \mathrm{Th}$ and ${ }^{40} \mathrm{~K}$ of soil samples of the first company has the highest activity concentration of ${ }^{226} \mathrm{Ra}$ while the third company has the lowest average activity concentrationas indicated in Figure2. Average specific activity of ${ }^{226} \mathrm{Ra},{ }^{232} \mathrm{Th}$ and ${ }^{40} \mathrm{~K}$ of soil samples under investigation are relatively higher than the reported values of ${ }^{226} \mathrm{Ra}$ and ${ }^{232} \mathrm{Th}$ in some countries such as Denmark, Poland and Greeceas reported by UNSCEAR (2000).

Table 4 shows results of the activity concentrations for ${ }^{226} \mathrm{Ra},{ }^{232} \mathrm{Th},{ }^{40} \mathrm{~K}$ and ${ }^{137} \mathrm{Cs}$ in waste. The values of slag are below worldwide concentrations in blast furnace slag $\left(150 \mathrm{~Bq} / \mathrm{kg}\right.$ for ${ }^{226}$ Raand ${ }^{232} \mathrm{Th}$ ) (UNSCEAR, 2000). The brick sample produced from EAF of the third company has activity concentrations $85.9,85.1,129.5$ and $4.1 \mathrm{Bqkg}^{-1}$ for ${ }^{226} \mathrm{Ra},{ }^{232} \mathrm{Th},{ }^{40} \mathrm{~K}$ and ${ }^{137} \mathrm{Cs}$ respectively and the presence of ${ }^{137} \mathrm{Cs}$ may be attributed to brick sample 
contaminated with EAFD. The EAFD of the fourthcompany has activity concentrations of ${ }^{226} \mathrm{Ra},{ }^{232} \mathrm{Th}$, ${ }^{40} \mathrm{~K}$ and ${ }^{137} \mathrm{Cs}$ are $13.5,7.02,656.7$ and $1.5 \mathrm{Bqkg}^{-1}$ respectively. Presence of ${ }^{137} \mathrm{Cs}$ in EAFD indicates that it might originate from scrap contaminated by ${ }^{137} \mathrm{Cs}$. This agrees with previous work (Tahir et al., 2010) who report edactivity of ${ }^{226} \mathrm{Ra}\left(5.9-13.3 \mathrm{Bqkg}^{-}\right.$ $\left.{ }^{1}\right),{ }^{232} \mathrm{Th}\left(3.9-8.3 \mathrm{Bqkg}^{-1}\right),{ }^{40} \mathrm{~K}\left(320-582 \mathrm{Bqkg}^{-1}\right)$ and ${ }^{137} \mathrm{Cs}\left(6.8-20.9 \mathrm{Bqkg}^{-1}\right)$ in the EAFD. The values of Scale are lower than values given by Bakr (2004) 9.5 $\mathrm{Bqkg}^{-1}$ for ${ }^{226} \mathrm{Ra}$ and $4.9 \mathrm{Bqkg}^{-1}$ for ${ }^{232} \mathrm{Th}$ in scale ofthe fourth company.

\section{The radiological hazard indices}

All $\mathrm{Ra}_{\text {eq }}$ values in present work are lower than the maximum permissible limit $\left(370 \mathrm{Bqkg}^{-1}\right)(\mathbf{U N}-$ SCEAR, 2000), which are acceptable for safe use except Bauxite from the fifth company (1009.3 $\left.\mathrm{Bqkg}^{-1}\right)$.

The average values of gamma radiation representative level index $\mathrm{I}_{\gamma}$ in soil samples are below the international maximum permissible value (1.0) (UNSCEAR, 2000), therefore the samples aren't radiologically hazardous except soil samples around the first company which have values(1.18 and1.77) and fluorspar from the third company (1.07) and Bauxite from the fifth company (6.94).

Both soil samples and raw materials have absorbed dose rate lower than world widean average value $\left(60 \mathrm{nGyh}^{-1}\right)$ reported by UNSCEAR (2000) except soil samples which have absorbed dose rates (74.2, and $120.2 \mathrm{nGyh}^{-1}$ ) around the first company and fluorspar from the third company and bauxite from the fifth company (69.37, and 442.7 $\mathrm{nGyh}^{-1}$ respectively).

The annual effective dosein both soil samples and raw materials is lower than the maximum permissible value for public $\left(1000 \mu \mathrm{Svy}^{-1}\right)$ according to ICRP (1990) except bauxite from the fifth company $\left(1009.3 \mu \mathrm{Svy}^{-1}\right)$.

The average values of AGED in both soil samples and raw materials are lower than the world av- erage $\left(0.3 \mathrm{mSvy}^{-1}\right)$ reported by UNSCEAR (2000) except the soil samples around the first company which have values $\left(0.553\right.$, and $\left.0.812 \mathrm{mSvy}^{-1}\right)$ and fluorspar from the third company $\left(0.49 \mathrm{mSvy}^{-1}\right)$ and bauxite from the fifth company which have values $\left(3.02 \mathrm{mSvy}^{-1}\right)$.

The average values of ELCRin soil samples and raw materials are lower than the world average of $0.29 \times 10^{-3}$ (UNSCEAR, 2000; ICRP, 2007; Taskin et al., 2009) except soil samples around the first company which have values $\left(0.319 \times 10^{-3}\right.$ and $\left.0.517 \times 10^{-3}\right)$ and bauxite from the fifth company $\left(1.9 \times 10^{-3}\right)$.

\section{Assessment of heavy metal pollution}

All heavy metals are within the worldwide natural range in all soil samples, except the concentrations of $\mathrm{Cd}$, and $\mathrm{Pb}$ in soil sample $\mathrm{S} 50$ (the third company), $\mathrm{Cu}$ in soil samples $\mathrm{S} 50$ (the third company) and S52 (the fourth company), Mn in soil samples S5, S13, S14, and S16 (the first company), and $\mathrm{Zn}$ in $45 \%$ of soil samples are higher than worldwide natural range. This may a result from contamination with electric arc furnace dust (EAFD)(Cappelletti et al., 2016).

The first company (sample S5) has the maximum concentration value for $\mathrm{Mn}$, the second company has the maximum concentration value for As, and Fe (samples S25, and S36 respectively, and the third company (sample S50) has the maximum concentration value for $\mathrm{Cd}, \mathrm{Cr}, \mathrm{Cu}, \mathrm{Ni}, \mathrm{Pb}$, and $\mathrm{Zn}$.

The abundance order of heavy metal in soil samples contents according to average concentration was: $\mathrm{Fe}>\mathrm{Mn}>\mathrm{Zn}>\mathrm{Cr}>\mathrm{Pb}>\mathrm{Cu}>\mathrm{Ni}>\mathrm{As}>\mathrm{Cd}$.

Sample S50 (the third company) has the highest contamination factor for $\mathrm{Cd}, \mathrm{Cr}, \mathrm{Cu}, \mathrm{Ni}, \mathrm{Pb}$, and $\mathrm{Zn}$, sample S36 (the second company) has the highest contamination factor for Fe, sample S5 (the first company) has the highest contamination factor for Mn and sample S25 (the second company) has the highest contamination factor for As. 
The third companyhas the highest average contamination factor for $\mathrm{Cd}, \mathrm{Cr}, \mathrm{Cu}, \mathrm{Ni}, \mathrm{Pb}$, and $\mathrm{Zn}$ and the second company has the highest average contamination factor for Fe, Mn and As.

The $\mathrm{C}_{\mathrm{deg}}$ average values classifiedthe states of the soil as very height degree of contamination, considerable degree of contamination, very height degree of contamination, very height degree of contamination andlow degree of contamination for the first company, the second company, the third company, the fourth company, and the fifth company, respectively. The third company has the highest average $\mathrm{C}_{\mathrm{deg}}$ (176) and the fifth company has the lowest average $\mathrm{C}_{\text {deg }}$ (4.6).

The PLI values classified the states of the soil asdeterioration of site quality, perfection of pollution, deterioration of site quality, deterioration of site quality and perfection of pollution for soils of the first company, the second company, the third company, the fourth company, and the fifth company, respectively. Sample S50 (the third company) has the highest pollution load index value and sample S63 (the fifth company) has the lowest pollution load index.

The most pollution zone is the third company (third zone) showing PLI $=3.3$ and the most contributed site is S50 (beside EAF) as a result of its elevated concentrations of $\mathrm{Cd}, \mathrm{Zn}$, and $\mathrm{Pb}$.

The first company has elevated pollution load index zone (1.26) because its samples S13, S14, and S16 have elevated concentrations of $\mathrm{Mn}, \mathrm{As}, \mathrm{Cd}$, and $\mathrm{Zn}$. The third company has elevated pollution load index zone (3.34) because its samples S44, S45, S49 and $\mathrm{S} 50$ have elevated concentrations of $\mathrm{Cd}, \mathrm{Zn}, \mathrm{Pb}$, and As. the fourth company has elevated pollution load index zone (1.33) because its sites S52, and $\mathrm{S} 56$, have elevated concentrations of $\mathrm{Cd}, \mathrm{Zn}$, and $\mathrm{Pb}$.

\section{CONCLUSION}

The average activity concentrations of ${ }^{226} \mathrm{Ra}$, ${ }^{232} \mathrm{Th}$ and ${ }^{40} \mathrm{~K}$ in soil samples is lower than worldwide average values 33, 45 and $412 \mathrm{Bqkg}^{-1}$ respectively (UNSCEAR, 2008). except ${ }^{226} \mathrm{Ra}$ and ${ }^{40} \mathrm{~K}$ in some soil samples around the first company may be attributed to contamination of soil during transportation of the waste to the storage area, where waste (blast furnace slag) of this company has elevated activity concentration of ${ }^{226} \mathrm{Ra}(551.7 \mathrm{~Bq} / \mathrm{kg})$ as reported by previous studies. The clear variation and elevation in ratios of ${ }^{226} \mathrm{Ra} /{ }^{232} \mathrm{Th}$ indicates that normal pattern of the soils may be affected by contamination of industry and human activities. The activity concentrations of ${ }^{137} \mathrm{Cs}$ for all soil samples are under the detection limit except S50, S47 and S48 in the third companyhave ${ }^{137} \mathrm{Cs}$ that may be related to contamination of soil by EAFD which transported by air and deposited into the soil. The presence of ${ }^{137} \mathrm{Cs}$ in EAFD may be as a result of using contaminated scrap in EAF. So, monitoring of artificial isotope ${ }^{137} \mathrm{Cs}$ in the scrap and EAFD is needed.

The activity concentrations of coke and slag in the present study are lower than the world average range and previous studies. Thermal brick sample from EAF of the third company, and EAFD from the fourth company have ${ }^{137} \mathrm{Cs}$ as a result of using contaminated scrap with ${ }^{137} \mathrm{Cs}$. So, monitoring of artificial isotope ${ }^{137} \mathrm{Cs}$ in the scrap and EAFD is necessary.

From the results of hazard indices, it has found that the soil samples and raw materials in study area are considered to be safe and can be used as a construction material without posing any significant health risk to the population except two soil samples S3, S19 (the first company), fluorspar from the third company and bauxite from the fifth company.

According to PLI of zones there are three polluted zones from the five studied zones. The most pollution zone is the third company showing PLI = 3.3 and the most contributed site is sample S50 (beside EAF) as a result of its elevated concentrations of $\mathrm{Cd}, \mathrm{Zn}$, and $\mathrm{Pb}$. 


\section{RECOMMENDATIONS}

To reduce and eliminate contamination and exposure due to iron \& steel industry in the future we recommended that:

1. The concentration of radioactive and heavy metals in the raw materials mustn't exceed the permissible limit.

2. Radiation monitoring of the used scrap to prevent producing radioactive iron and radioactive waste.

3. Monitoring for ${ }^{137} \mathrm{Cs}$ in the dust of the EAFD before leaving the production cycle to protect the environment from pollution through the use of dust in other industries or during its disposal.

4. Factory workers must know how to handle the resulting waste materials and wearing protective cloths during the process are necessary.

5. The resulting waste from the iron and steel industry should be collected and transported in sealed vehicles to storage area to prevent exposure of workers and the environment to the radiation dose and contamination with radioactive and heavy metals.

6. The governmental and organizational bodies must periodically monitorenvironmental samplesaround iron and steel factories to detect any increase in the radioactive and heavy metals concentrationand the polluted soil should be remediated.

7. It is recommended that effective remediation strategy and environmental management plan is required to control and reduce the input of toxic metals $(\mathrm{Cd}$ and $\mathrm{Pb})$, which would significantly minimize the potential of further pollution of the environment.

This study can be used as a database for future investigations and the data obtained in this study may be useful for natural radioactivity mapping. The results may also be used as a reference data for monitoring possible radioactivity pollutions in future.

\section{REFERENCES}

- Abdel-Ghany, H. (2010): Natural activities of ${ }^{238} \mathrm{U}$, ${ }^{232} \mathrm{Th}$ and ${ }^{40} \mathrm{~K}$ in manganese ore, Am EnvSci, 6:90.

- Alam, M.N.; Chowdhury, M.I.; Kamal, M.; Ghose, S.; Banu, H. and Chakraborty, D. (1997): Radioactivity in chemical fertilizers used in Bangladesh. Appl. Rad. Isot, 48: 1165.

- Alloway, B. (1990): Heavy metals in soils. Glasgow: Blackie Academic and Son Ltd 339.

- Avwiri, G.O.; Ononugbo, C.P. and Nwokeoji I.E. (2014): Radiation hazard indices and excess lifetime cancer risk in soil, sediment and water around miniokoro/oginigbacreek, Port Harcourt, rivers state, Nigeria. Compr. J. Environ. Earth Sci., 3(1):38.

- Bakr, W. (2004): Integrated Safety Plan for the Radiological Impact of Some Non-Nuclear Industries, PhD Thesis, Chemistry Department, Ain-Shams University, Cairo, Egypt.

- Beretka, J. and Mathew, P.J. (1985): Natural radioactivity of Australian building materials, industrial wastes and by-products. Health Phys., 48: 87.

- Brumelis, G.; Brown, D.; Nikodemus, O. and Tjarve, D. (1999): The monitoring and risk assessment of $\mathrm{Zn}$ deposition around a metal smelter in Latvia. Environ. Monit. Assess., 58(2):201.

- Cappelletti, R.; Marcello, C.; Justina, C. and Valerio, G. (2016): Health status of male steel workers at an electric arc furnace (EAF) in Trentino, Italy. J. Occup. Med. Toxicol., 11:7.

- Currie, L.A. (1968): Limits for qualitative detection and quantitative determination. Application to radiochemistry. Anal. Chem., 40(4): 586.

- EC (2015): European Commission, Natural radiations atlas. Joint Research Centre publications. https://rem.jrc.ec.europa.eu/re mweb/ activities. aspxid $=$ natradatlas. 
- El-Tahawy, M.; Farouk, M.; Hammad, F. and Ibrahim, N. (1992): Natural potassium as a standard source for the absolute efficiency calibration of germanium detectors, J. Nucl. Sci., 29(1):361.

- EPA (2007): Environmental Protection Agency, March 2007. EPA-402- F-06-061.United States. Ionizing Radiation, Fact Book.

- EPA (1996): Environmental Protection Agency, Method 3050B, Acid Digestion of Sediments, Sludges, and Soils, Revision 2.

- Hakanson, L. (1980): An Ecological Risk Index for Aquatic Pollution Control a Sedimentological Approaches. Water Res., 14(8):975.

- Huang, Y.; Lu, X.; Ding, X. and Feng, T. (2015): Natural radioactivity in beach sand along coast of Xiamen Island, China. Mar. pollut. Bull., 91:357.

- IAEA (1989): International Atomic Energy Agency, construction and use of calibration facilities radiometric field equipment, Technical Report Series No.309, Vienna.

- ICRP (1990): International Commission on Radiological Protection. Recommendations of the international Commission on radiological protection. ICRP Publication, 60 Ann.

- ICRP (2007): The 2007 Recommendations of the International Commission on Radiological Protection. ICRP Publication 103. Ann ICRP 37(2-4).

- ICRP (2008): Nuclear Decay Data for Dosimetric Calculations. ICRP Publication 107.Ann. ICRP 38 (3).

- Integrated Management System Manual (2005): Al-Ezz Steel Rebars Company, Jan, 25.

- IPPC (2001): Integrated Pollution Prevention and Control, best available techniques reference document on the production of iron and steel. European Commission, European IPPC Bureau, Sevilla.

- Kaleel, M. and Mohanad, M. (2012): Natural radioactivity levels and estimation of radiation exposure in environmental soil samples from Tulkarem ProvincePalestine. J. Soil Sci., 2:7.
- Keck, R.; Kruger, B. and Kretschmer, R. (1994): Metrological possibilities for detecting radioactive sources in scrap. Messtechnische Moeglichkeiten zum Nachweis von radioaktiven Quellen im Schrott. Stahl Eisen., 114:8.

- Knoll, G.F. (1998): Radiation Detection and Measurement, $3^{\text {rd }}$ ed. New York.

- Krzysztof, L.; Wiechula, D. and Korns, I. (2003): Metal contamination of farming soils affected by industry. Environ. Int., 30:159.

- Kugeler, E. and Thierfeldt, S. (1999): Detection of radioactivity in scrap in Germany. Proceedings of workshop on radioactive contaminated metallurgical scrap. United Nations. Economic Commission for Europe, Prague, Czech Republic, 26-28 May 1999, 165.

- Kurnaz, A.; Küçükömeroğlu, B.; Keser, R.; Okumusoglu, N.T.; Korkmaz, F.; Karahan, G. andCevik, U. (2007): Determination of radioactivity levels and hazards of soil and sediment samples in Firtina Valley (Rize, Turkey). Appl. Rad. Isot., 65:1281.

- Leet, L.; Judson, S. and Kauffman, M. (1982): Physical Geology. $6^{\text {th }}$ ed. New Jersey: Prentice - Hall Inc.

- Lindsay, W.L. (1979): Chemical equilibria in soils. New York: John Wiley and Sons.

- Lopez, F.; Sainz, E.; Lopez-Delgado, A.; Pascual, L. and Fernandez Navarro, J. (1996): The use of blast furnace slag and derived materials in the vitrification of electric arc furnace dust. Metall. Mater. Trans., 27B: 379 .

- Nadeem, R.; Waseem, R.; Zafar, I.; and Kumar, R. (2016): Beneficiation of Zinc from electric arc furnace dust using hydrometallurgical approach. Russ. J. Appl. Chem., 89 (5):836.

- Ndontchueng, M.M.; Nguelem, E.J.M.; Njinga, R.L.; Simo, A. and Guembou, J.C.S. (2014): Gamma emitting radionuclides in soils from selected areas in Douala-Bassa zone, littoral region of Cameroon. ISRN Spectrosc, 2014:1. doi:10.1155/2014/245125. 
- NEA-OECD (1979): Nuclear Energy Agency. Exposure to radiation from natural radioactivity in building materials, Report by NEA group of experts.Paris, France, OECD.

- Qureshi, A.A.; Tariq, S.U.; Din, K.; Manzoor, S.; Calligaris, C. and Waheed, A. (2014): Evaluation of excessive lifetime cancer risk due to natural radioactivity in the rivers sediments of northern Pakistan. $J$. Radiat. Res. Appl. Sci, 7(2):1.

- Ramasamy, V.; Suresh, G.; Meenakshisundaram, V. and Ponnusamy, V. (2011): Horizontal and vertical characterization of radionuclides and minerals in river sediments. Appl. Rad. Isot., 69:184.

- Ravisankar, R.; Vanasundari, K.; Suganya, M.; Raghu, Y.; Rajalakshmi, A.; Chandrasekaran, A.; Sivakunar, S.; Chandramo-han, J.; Vijayagopal, P. and Venkatraman, B. (2014): Multivariate statisticalanalysis of radiological data of building materials used in Tiruvan-namalai, Tamilnadu, India. Appl. Rad. Isot., 85:114.

- Roessier, C.E.; Smith, Z.A.; Bloch, W.E. and Prince, R.J. (1970): Uranium and radium in Floride phosphate materials. Health Phys., 37:269.

- Samad, M.A.; Ali, M.I.; Paul, D. and Islam, S.M., (2012): Assessment of radiological significance of the wastes generated from the triple super phosphate (TSP) fertilizer factory, Chittagong, Bangladesh. $J$. Bangl. Acad. Sci., 36:79.

- Shanthi, G.; Thampi, J.T.K.; Allen, G.G.R. and Maniyan, C.G. (2010): Measurement of activity concentration of natural radionuclides for the assessment of radiological indices. Radiat. Prot. Dosim., 141(1):90.

- Surinder, S.; Baldev, S. and AjayKumar, (2003): Natural radioactivity measurements in soil samples from Hamirpur district, Himachal Pradesh, India. Radiat. Meas., 36:547.

- Tahir, S.; Delko, B. and Una, S. (2010): Monitoring of Cs-137 in electric arc furnace steel making process. J. Radioanal. Nucl. Chem., 284:615.
- Taskin, H.; Karavus, M.; Ay, P.; Topuzoglu, A.; Hidiroglu, S. and Karahan, G. (2009): Radionuclide concentration in soil and lifetime cancer risk due to the gamma radioactivity in Kirklareli, Turkey. J. Environ. Radioact., 100:49.

- The First Environmental Conference for Al-EzzDekhiela Group (2004): Alexandria National Iron \& Steel Company, Alexandria, Egypt, 11-12 Oct.

- Tippie, V.K. (1984): An environmental characterization of Chesapeake Bay and a frame work for action. In: Kennedy, V. (ed) The estuary as a filter. New York: Academic Press

- Tomlinson, D.; Wilson, J.; Harris, C. and Jeffrey, D. (1980): Problems in the assessment of heavy metal levels in estuaries and the formation of a pollution index. Helgol. Meeresunters., 33:566.

- Tufail, M.; Nasim, A. and Waqas, M. (2006): Measurement of Terrestrial Radiation for Assessment of Gamma Dose from Cultivated and Barren Saline Soils of Faisalabad in Pakistan. Rad. Meas., 41:443.

- Udosen, E.; Udoessien, E. and Ibok, U. (1990): Evaluation of some metals in the industrial wastes from a paint industry and their environmental pollution implications. Nigerian J. Technol. Res., 2:71.

- Umland, J. and Bellama, J. (1996): General Chemistry. $2^{\text {nd }}$ ed. Minneapolis: West Publishing Company.

- UNSCEAR (2000): Sources and effects of ionizing radiation. Report of the United Nations Scientific Committee on the Effects of Atomic Radiation to the general Assembly. New York, USA: United Nations.

- UNSCEAR (2008): Sources and Effects of Ionizing Radiation, Annex B: Exposures of the public and workers from various sources of radiation. United Nations Scientific Committee on the effects of Atomic Radiation, New York.

- Usero, J.; Garcia, A. and Fraidias, J. (2000): Calidad de las Aguas y Sedimentos del Litoral Andaluz. In: Junta de Andalicia, Consejeria del Medio Ambiente, Sevilla: 164. 
- Vohra, G.; Pillai, K.C. and Sadavisan, S. (1982):

Natural radiation environment. New York: Halsted

Press

- Wei, B. and Yang, L. (2010): A review of heavy metal contaminations in urban soils, urban road dusts and agricultural soils from China. Microchem. J., 94:99. doi: 10.1016/j.microc.2009.09.014.

- Yaylali-Abanuz, G. (2011): Heavy metal contamination of surface soil around Gebze industrial area, Turkey. Microchem. J, 99: 82.

- Zivanovic, M.; Nikolic, J.; Apostol, A. and Anagnostakis, M. (2012): Analysis of interferences from full energy peaks in gamma spectrometry of NORM and TENORM samples. Nucl. Technol. Radiat. Prot., 27(4): 380 . 